\title{
Tectonometamorphic history of the Gruf complex (Central Alps): exhumation of a granulite- migmatite complex with the Bergell pluton
}

\author{
Journal Article \\ Author(s): \\ Galli, Andrea; Le Bayon, Benjamin; Schmidt, Max W.; Burg, Jean-Pierre; Reusser, Eric \\ Publication date: \\ 2013 \\ Permanent link: \\ https://doi.org/10.3929/ethz-b-000071188
}

Rights / license:

In Copyright - Non-Commercial Use Permitted

Originally published in:

Swiss Journal of Geosciences 106(1), https://doi.org/10.1007/s00015-013-0120-1 


\title{
Tectonometamorphic history of the Gruf complex (Central Alps): exhumation of a granulite-migmatite complex with the Bergell pluton
}

\author{
Andrea Galli • Benjamin Le Bayon - Max W. Schmidt • \\ Jean-Pierre Burg • Eric Reusser
}

Received: 19 September 2011 / Accepted: 31 January 2013

(C) Swiss Geological Society 2013

\begin{abstract}
We describe field occurrences of sapphirinebearing granulites, charnockites and migmatites in the Gruf complex, Central Alps and present a new geological map and a structural analysis of the entire Gruf complex for the first time. We have carried out an accurate analysis of the relationships between granulite facies metamorphism, migmatisation and deformation within the complex, in relation to the intrusion of the Bergell pluton. Granulites and charnockites display fabrics different from those defined by the regional foliation and lineation, which are, typically for migmatites, disordered on the mesoscale. On a regional scale, strike variations are also related to the structural complexity of migmatites within which no major antiform could be identified. Irregular interfingering of subparallel leucosome veins and back-veining along the contact between the Gruf migmatites and the Bergell tonalite are evidence for contemporaneous emplacement and crystallisation at about $740{ }^{\circ} \mathrm{C}$ and $6.5-7.5 \mathrm{kbar}$ in Oligocene times (ca $30 \mathrm{Ma}$ ). Metamorphic conditions in the charnockites and granulites $\left(>920{ }^{\circ} \mathrm{C}\right.$ for $\left.8.5-9.5 \mathrm{kbar}\right)$ largely
\end{abstract}

Editorial handling: Stefan Schmid and A. G. Milnes.

Electronic supplementary material The online version of this article (doi:10.1007/s00015-013-0120-1) contains supplementary material, which is available to authorized users.

A. Galli · B. Le Bayon · M. W. Schmidt · J.-P. Burg ·

E. Reusser $(\bowtie)$

Department of Earth Sciences, ETH Zurich,

Sonneggstrasse 5, 8092 Zurich, Switzerland

e-mail: eric.reusser@erdw.ethz.ch

Present Address:

B. Le Bayon

BRGM, 3 Avenue Claude-Guillemin, BP 36009,

45060 Orléans Cedex 2, France exceed these regional metamorphic conditions and are dated at 282-260 Ma. We propose that the ascending Bergell pluton entrained the polymetamorphic, granulitic lower crust enclosed within the peripheral migmatitic Gruf complex.

Keywords Lepontine Alps · Gruf complex - Granulite · Charnockite $\cdot$ Migmatisation

\section{Introduction}

The occurrence of high grade metamorphic rocks such as sapphirine-bearing granulites and charnockites (Cornelius 1916; Wenk et al. 1974; Galli et al. 2011) and widespread migmatisation (Berger et al. 1996; Davidson et al. 1996) make the Gruf complex unique within the Central Alps. It is crucial to understand such rocks in modern orogenic systems and, from a more regional point of view, these distinct rocks need to be integrated into the tectonometamorphic evolution of the Lepontine Alps. The location of the Gruf complex (Fig. 1), structurally directly below the Bergell pluton (Rosenberg et al. 1995), also offers the opportunity to investigate the relationships between the ascent and emplacement of a tonalitic pluton and deformation within neighbouring country rocks (Davidson et al. 1996).

Mostly because of its hostile topography, the Gruf complex remained one of the least investigated areas of the Alpine chain. Here, the Gruf complex is understood as the geological unit between the Bergell intrusion (to the south and east), the ophiolitic Chiavenna unit (to the north), and the Valle della Mera (to the west). The existing geological maps cover only small parts of this complex (north-eastern part by Wenk and Cornelius 1977; southernmost part by 


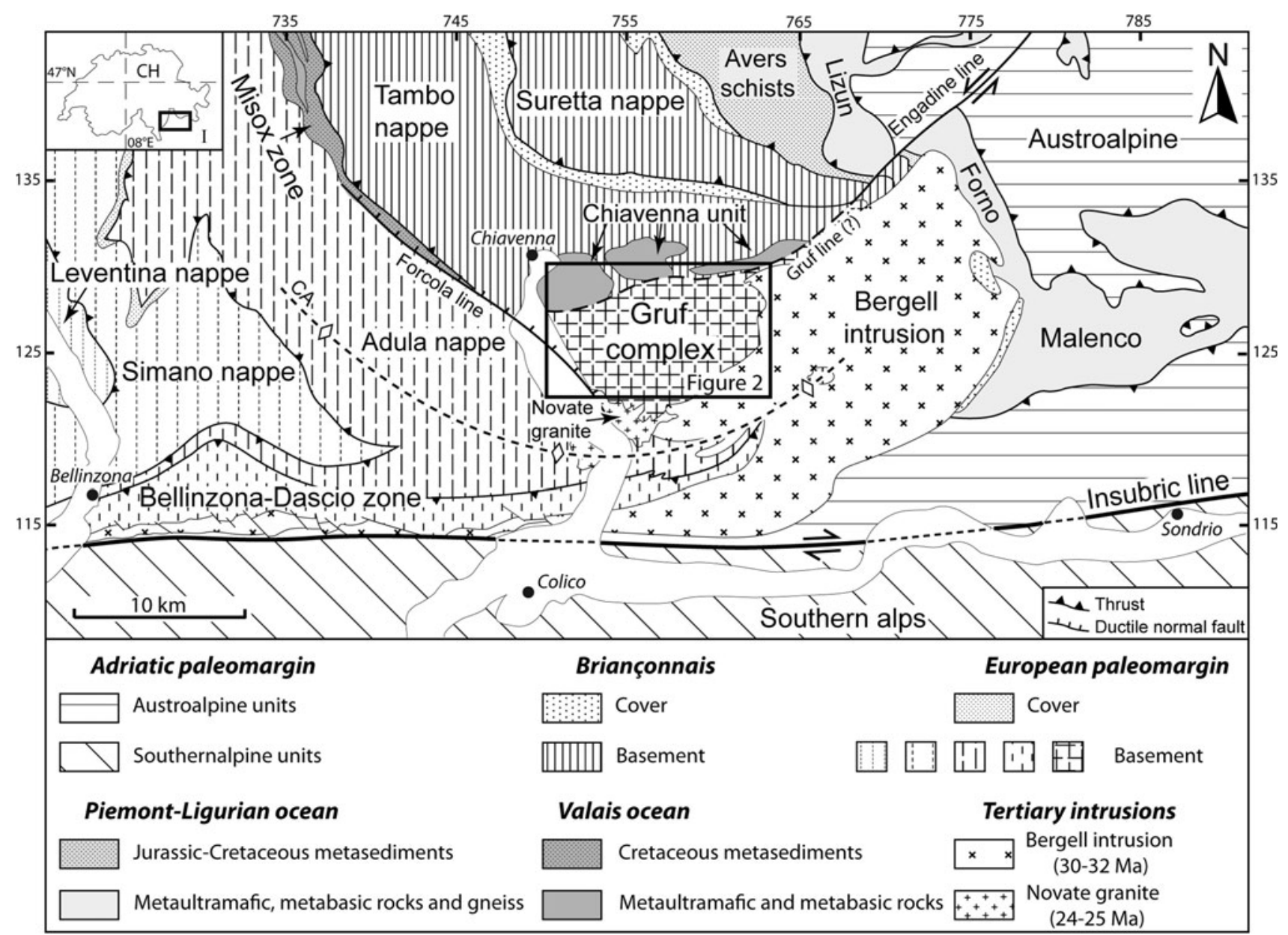

Fig. 1 Simplified map of the eastern Central Alps (SE Switzerland and N Italy, see inset). Main units patterned and classified according to their paleogeographical origin. Framed: studied area (Fig. 2). Swiss co-ordinates given in kilometres. CA Cressim antiform

Moticska 1970); for most of the complex detailed maps or other field information are not available. The few available petrological (Bucher-Nurminen and Droop 1983; Droop and Bucher-Nurminen 1984; Diethelm 1989) and geochronological (Gulson 1973; Liati and Gebauer 2003; Schmitz et al. 2009) investigations were mostly performed using fallen blocks; hence there is no documentation regarding the tectonic or geological context of the samples. Since detailed mapping, a prerequisite for developing a coherent structural scheme of the Gruf complex, is missing, there is no consensus on the tectonic position of the Gruf complex within the Penninic nappes yet. Three interpretations have been proposed so far: the Gruf complex (i) constitutes the eastern continuation of the Adula nappe (Schmid et al. 1996a, b; Davidson et al. 1996; Frey and Ferreiro Mählmann 1999; Berger et al. 2005); (ii) is equivalent to the Bellinzona-Dascio zone (Wenk 1973; Wenk and Cornelius 1977; Milnes and Pfiffner 1980); (iii) represents an independent unit (Staub 1946; Hänny et al. 1975).
We present a geological map of the entire Gruf complex (Fig. 2), and detailed geological profiles (Fig. 3), together with a structural analysis and an investigation of the relations between migmatisation, deformation and the intrusion of the Bergell pluton. The major aims of this paper are to: (i) characterise the rock types that constitute the Gruf complex, their field relations and the relations with the adjacent Chiavenna ophiolite and the Bergell pluton; (ii) perform a coherent structural analysis; (iii) investigate the field characteristics and metamorphic conditions during migmatisation; (iv) understand the role of the Bergell intrusion during the exhumation of the Gruf complex, and (v) integrate the Gruf complex into the tectonic and metamorphic evolution of the Central Alps in general.

\section{Geological setting}

The Alps result from the convergence between the European and Adriatic paleo-margins, which led to the closure 


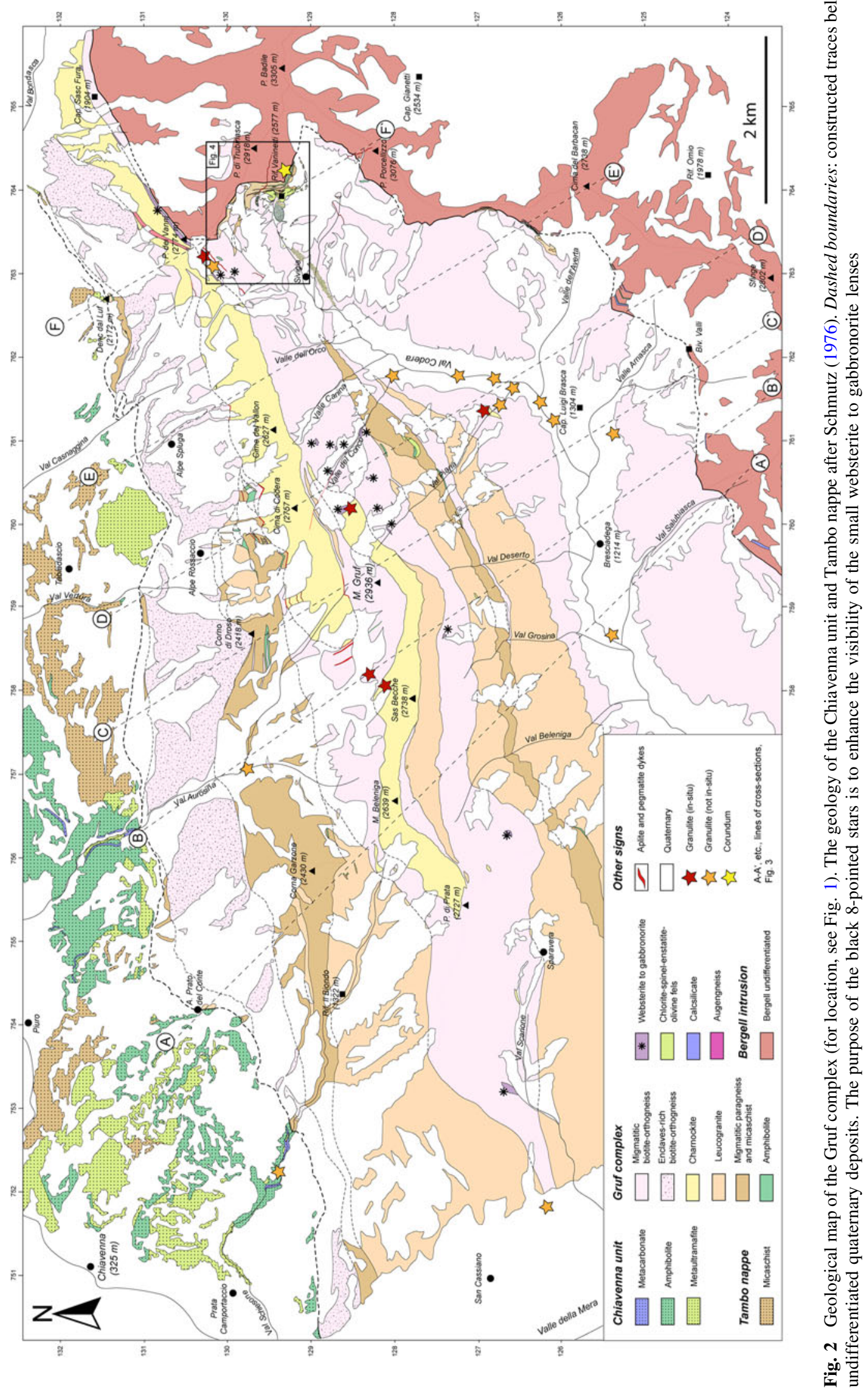




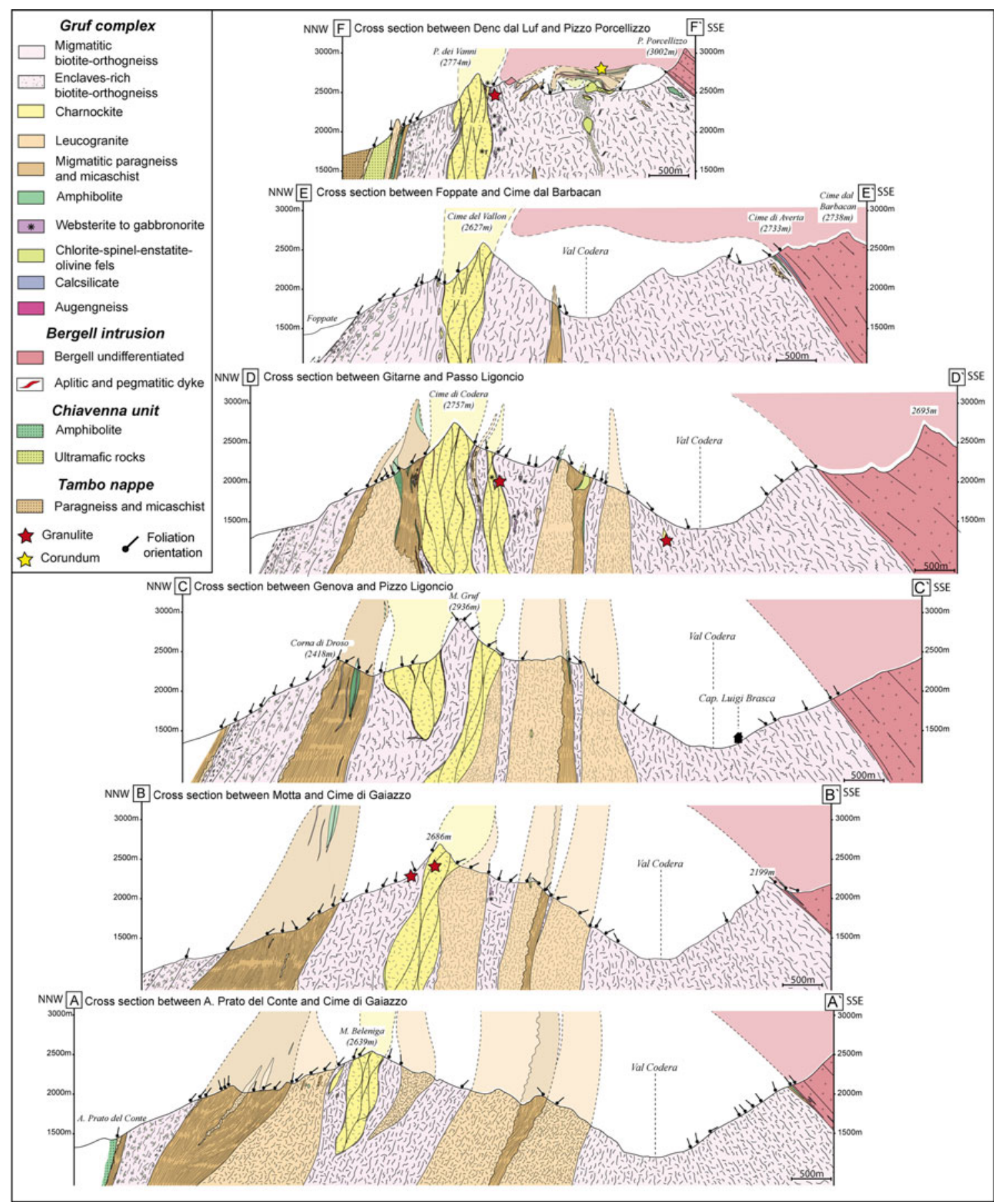

Fig. 3 Geological cross-sections through the Gruf complex. Nomenclature of lithologies and locations in Fig. 2. No vertical exaggeration

of two oceanic basins, the Piemont-Liguria and Valais oceans (e.g. Milnes and Pfiffner 1980; Schmid et al. 1996a). The stack of the Penninic nappes in the Central Alps formed during south-dipping subduction of the European plate and subsequent continental collision with Adria. Five main paleogeographic domains are recognized in the Central Alps, (Fig. 1): (i) the Leventina, Simano and Adula nappes are ascribed to the distal parts of the
European continental margin (Trümpy 1960; Schmid et al. 1990, 1996a); (ii) the ophiolites of the Misox zone and Chiavenna are interpreted as remnants of the Valais ocean (Schmid et al. 1996a; Steinmann and Stille 1999); (iii) the Tambo and Suretta nappes represent slivers of the former Briançonnais micro-plate or crustal fragment (Schmid et al. 1990) separating Piemont and Valais oceanic domains from each other; (iv) the ophiolitic Malenco-Forno-Lizun- 
Avers units are assigned to the Piemont-Liguria ocean (Staub 1946; Schmid et al. 1990, 1996a), and, (v) the overthrust Austroalpine units correspond to the Adriatic continental margin (Handy et al. 1993; Froitzheim et al. 1994).

In this nappe stack, coherent allochthonous basement sheets such as the Leventina, Simano, Tambo and Suretta nappes are accompanied by more heterogeneous units such as the Adula-Cima Lunga nappe, the Gruf complex and the Bellinzona-Dascio zone (Berger et al. 2005). These lithologically heterogeneous units were referred to as an "Alpine lithospheric mélange" by Trommsdorff (1990) and interpreted as parts of a "tectonic accretion channel" (TAC), accreted at mantle depth during subduction (Engi et al. 2001).

The metamorphic pattern of the Central Alps is characterised by two major metamorphic events. An older lowto medium-temperature, high-pressure metamorphism is preserved as relics of blueschist- and eclogite-facies mineral assemblages in metasediments of domains (ii) and (iii) (Ring 1992; Baudin and Marquer 1993; Nussbaum et al. 1998; Bousquet et al. 2002) and as eclogites of mainly metabasaltic and peridotitic composition in the AdulaCima Lunga nappe (Heinrich 1982, 1986; Meyre et al. 1999; Nimis and Trommsdorff 2001; Dale and Holland 2003; Berger et al. 2005; Brouwer et al. 2005; Zulbati 2008). This first metamorphic event is related to subduction and followed by a second Barrow-type event ("Lepontine metamorphism"), which strongly overprinted pre-existing mineral assemblages. Concentric isograds, isotherms and isobars define the "Lepontine Metamorphic Dome" (Wenk 1955; Todd and Engi 1997). This pattern cuts across nappe boundaries, suggesting that the Barrow-type peak-metamorphic-conditions were reached after nappe emplacement (Niggli and Niggli 1965; Wenk 1970; Trommsdorff 1966; Bernotat and Bambauer 1982; Todd and Engi 1997; Berger et al. 2011; Wiederkehr et al. 2008). Barrow-type metamorphic conditions increase southwards from upper greenschist- to upper amphibolite-facies. In the southern central part, the Lepontine dome is characterised by migmatisation (Berger et al. 2005; Burri et al. 2005) that took place through fluid-assisted melting (Berger et al. 2008) at about $700{ }^{\circ} \mathrm{C}$ and 6-8 kbar (Nagel et al. 2002; Burri et al. 2005) between 32 and 22 Ma (Hänny et al. 1975; Köppel et al. 1981; Gebauer 1996; Berger et al. 2009; Rubatto et al. 2009). Further to the south, the Lepontine dome is truncated by the Insubric line (Fig. 1), a major tectonic boundary separating the high-grade Central Alps from the Southern Alps, which record only very low grade Alpine metamorphism (Schmid et al. 1987, 1989; Steck and Hunziker 1994).

The Gruf complex, in map view covering an area of about $20 \times 10 \mathrm{~km}$ (Figs. 1, 2), is located in the southeastern part of the Lepontine dome. To the north, the putative Gruf line, described as a vertical, strongly recrystallised mylonite zone (Schmutz 1976), separates the Gruf complex from the Chiavenna ophiolite and the Tambo nappe (Fig. 1). To the east and south, the Gruf complex is intruded by the calc-alkaline Bergell pluton, which formed from 33 to $30 \mathrm{Ma}$ (Von Blanckenburg 1992; Oberli et al. 2004; Gregory et al. 2009). To the west and south, the Gruf complex is bordered by the Adula nappe, the 24-25 Ma old Novate granite (Liati et al. 2000) and the Bergell pluton. The gneissic units between the northern and the southern limbs of the Bergell pluton are assigned to the Adula nappe and Bellinzona-Dascio zone (e.g. Berger et al. 1996, Fig. 1). The Gruf complex is dominated by migmatitic orthogneisses, paragneisses and micaschists. Upper amphibolite-facies migmatisation (Bucher-Nurminen and Droop 1983; Nagel et al. 2002) occurred between 34 and $29 \mathrm{Ma}$ (Liati and Gebauer 2003; Galli et al. 2012). Highpressure rocks known from the adjacent Adula nappe are absent in the Gruf complex. Rare sapphirine-bearing granulites, discovered by Cornelius (1916) and Wenk et al. (1974) only in the form of loose blocks in Val Codera, in fact form schlieren within charnockites and residual enclaves, both within migmatitic orthogneisses and charnockites (Galli et al. 2011). Granulites and charnockites formed under ultra-high temperature conditions of $T=920-940{ }^{\circ} \mathrm{C}$ and $P=8.5-9.5 \mathrm{kbar}$ (Galli et al. 2011). Droop and Bucher-Nurminen (1984), Liati and Gebauer (2003) and Schmitz et al. (2009) suggested an Alpine age for the granulites, whereas Huber (1999), Burri et al. (2005) and Galli et al. (2011) envisaged a pre-Alpine age. Subsequently, the charnockites have been dated at 282-260 Ma (U-Pb on zircon) placing granulite facies conditions in the Permian (Galli et al. 2012).

Numerous up to $100 \mathrm{~m}$ large lenses and cm-sized nodules of ultramafic, mafic, calcareous and pelitic compositions occur within the migmatites (Artus 1959; Moticska 1970; Wenk 1973, 1982, 1986, 1992; Diethelm 1989, Galli et al. 2011). These lenses and nodules are prevalently concentrated in proximity to the Bergell pluton (Moticska 1970; Wenk and Cornelius 1977) and are regarded as remnants of the North Penninic suture connecting the mafic-ultramafic Chiavenna unit and the Misox zone in the north with the Bellinzona-Dascio zone in the south (Diethelm 1989; Davidson et al. 1996; Schmid et al. 1996a), the latter also containing abundant ophiolite remnants (Schmidt 1989; Stucki et al. 2003). In summary, the Gruf complex is a composite unit, dominated by amphibolite facies ortho-gneisses of mostly Permian age and by migmatitic metasediments (Galli et al. 2012), but also featuring a Permian granulite-charnockite association as well as an ophiolitic rock suite that remains undated but lithologically resembles the ophiolites of the Chiavenna 


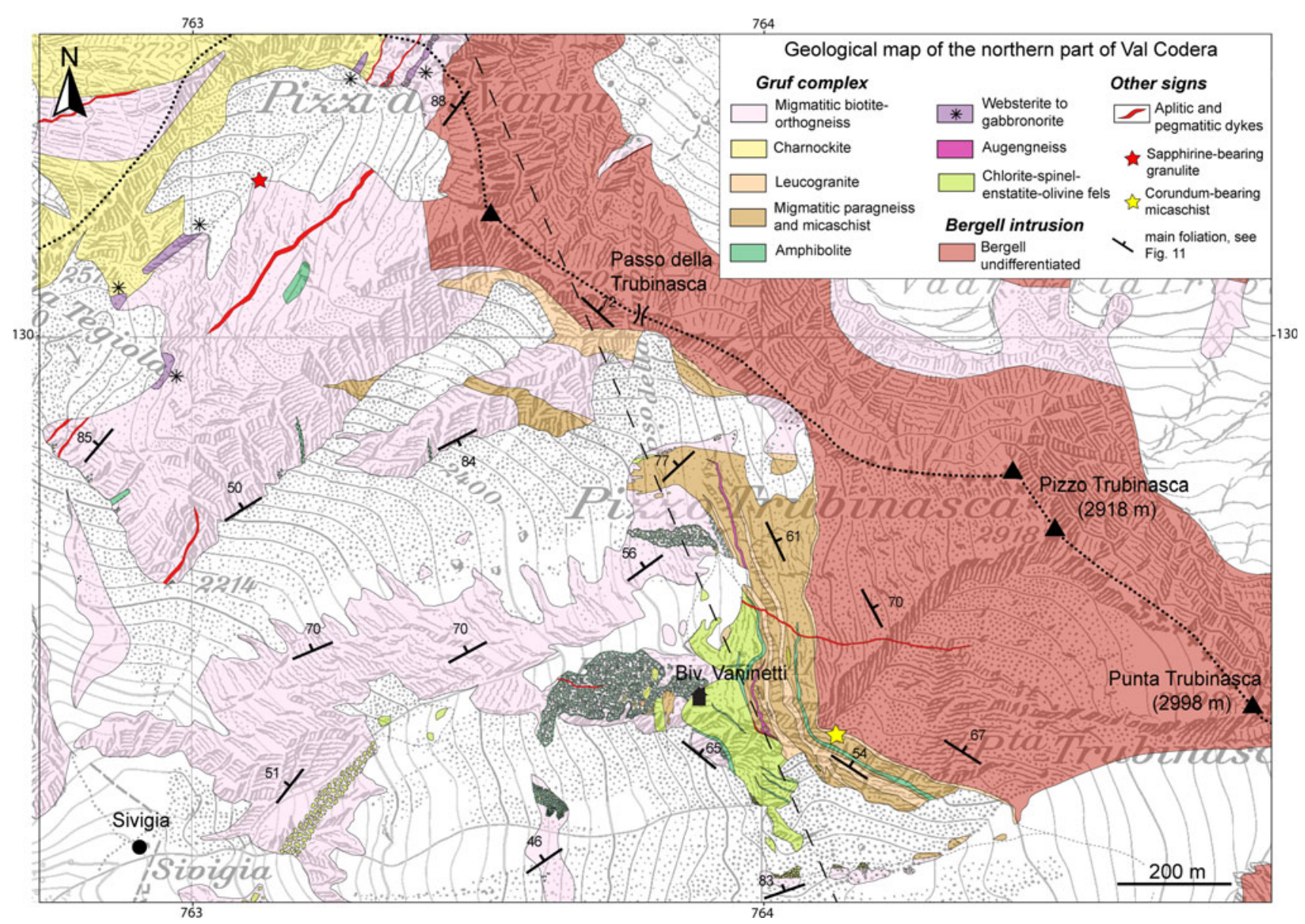

Fig. 4 Detailed geological map of the contact between the Gruf complex and the Bergell intrusion near Bivacco Vaninetti (for location, see Fig. 2), showing the largest ultramafic lenses within the

unit and Bellinzona-Dascio zone. High-pressure metamorphism, characteristic for the Adula nappe, has not been reported from the Gruf complex so far, while granulitecharnockite associations that are characteristic for the Gruf complex are absent in the Adula nappe.

\section{Lithological characterisation of the Gruf complex}

The Gruf complex essentially contains two groups of rock types: (i) migmatitic metagranitoids and (ii) partly migmatitic pelitic to psammitic metasediments (Figs. 2, 3). Small lenses of meta-ultramafic, -basic and -carbonate rocks occur within these two major groups, most prominently near Bivacco Vaninetti in the northeastern part of the Gruf complex (Fig. 4).

All these rock types, further described below, are commonly intruded by up to $5 \mathrm{~m}$ thick aplite and pegmatite dykes throughout the Gruf complex. Aplites and pegmatites are mostly composed of quartz, plagioclase, alkali feldspar and variable amounts of muscovite, biotite
Gruf gneisses and several magmatic breccia occurrences with ultramafic and mafic components. The stippled straight line crossing the map indicates the location of profile F of Fig. 3

and garnet. Tourmaline and beryl occur locally (Ghizzoni and Mazzoleni 2005). These dikes will not be discussed further.

\subsection{Metagranitoids and rock types enclosed therein}

\subsubsection{Migmatitic biotite-orthogneiss}

Migmatitic biotite-orthogneisses occur along the southern upper flank of Val Chiavenna and form the main part of Val Codera (Fig. 2). This rock type appears greyish, coarsegrained and mainly consists of quartz, plagioclase, alkali feldspar and biotite. Its migmatitic character is expressed by a weak stromatic structure of alternating leucocratic, quartz and feldspar rich-bands, and melanocratic, biotite-rich bands. Accessory minerals are muscovite, chlorite, epidote, apatite, rutile, sphene, ilmenite and zircon. Quartz forms subhedral to anhedral grains with undulose extinction, up to $1 \mathrm{~mm}$ in size. Plagioclase occurs as up to $2 \mathrm{~mm}$ large subhedral grains. Alkali feldspar is euhedral to subhedral, perthitic and up to $1.5 \mathrm{~cm}$ in size. Biotite forms acicular, 
millimetric flakes displaying a moderate preferred orientation. Generally, the migmatitic biotite-orthogneiss is massive or weakly foliated and shows unsystematic migmatitic structures (Figs. 5a, 6a). In Val Aurosina, Valle del Conco and around Bivacco Vaninetti, this rock type is intensely overprinted by ductile shear zones (Fig. 6b). Meter-sized enclaves and up to a few hundred meters large lenses of basic (Fig. 5b), charnockitic (Fig. 6c, d), granulitic (Galli et al. 2011), lherzolitic (Fig. 5f), websteritic to gabbronoritic (Fig. 5c), calcareous and pelitic composition (Fig. 5d) occur throughout this biotite-orthogneiss (Fig. 2).

\subsubsection{Enclave-rich biotite-orthogneiss}

Enclave-rich biotite-orthogneiss constitute the northernmost part of the Gruf complex. They form a rim of variable thickness (200-1,200 m) south of the Chiavenna unit, along the southern flank of Val Chiavenna between Prata Camportaccio and Val Bondasca (Figs. 2, 3). This rock type is coarser grained and it contains more biotite and less alkali feldspar compared to the migmatitic biotite-orthogneiss. Numerous, decimetric to metric, internally undeformed or well foliated, rounded to elongated enclaves of mainly mafic composition characterise this metagranitoid. Enclaves originally constituted by amphibole (Fig. 5b) and plagioclase are strongly overgrown by biotite. Rare pelitic, ultramafic and calcareous xenoliths also occur. The biotiteorthogneiss itself is mineralogically homogeneous and composed of subhedral to anhedral, up to $1 \mathrm{~mm}$ large quartz grains, subhedral, up to $2.5 \mathrm{~mm}$ large plagioclase grains, subhedral, up to $7 \mathrm{~mm}$ large, perthitic alkali feldspar grains and acicular, up to $2.5 \mathrm{~mm}$ large biotite flakes. Muscovite, chlorite, apatite, epidote, sphene, ilmenite and zircons are accessories. This enclave-rich biotite orthogneiss displays no or a weak foliation. The contact with the migmatitic biotite-orthogneiss to the south-southeast is diffuse and marked by grain-size reduction, particularly concerning biotite, and the progressive disappearance of mafic enclaves towards the enclave-free migmatitic biotite-orthogneiss.

\subsubsection{Charnockite}

On the meso-scale, the charnockites constitute internally boudinaged, sheet-like bodies surrounded by anatomising mylonite zones (Fig. 6c). Two major, up to $0.5 \mathrm{~km}$ thick and $8 \mathrm{~km}$ long charnockite-rich large bodies can be mapped near the crest between Val Chiavenna and Val Piana. Intermediate size charnockite lenses $(<100 \mathrm{~m})$ also occur in Val Piana, Valle del Conco, Val Scarione and Val Aurosina (Figs. 2, 3). This rock type is leucocratic, with a pronounced brownish weathering colour and medium to coarse-grained. It has an extremely weak fabric and is mostly composed of quartz, plagioclase, and perthitic alkali feldspar: in part it contains corroded orthopyroxene as well as rare biotite \pm garnet and sillimanite (Fig. 7a). Within the charnockite units, about $50 \%$ of the rocks contain macroscopically visible orthopyroxene. Outside the charnockite units as mapped in Fig. 2 we have not identified outcrops with charnockites. The internal structure of the charnockitic bodies is characterised by an irregular foliation wrapping around decimetric biotite-rich enclaves and meter-sized schlieren comprising mostly fine-grained biotite and millimetric garnet. The contacts to the neighbouring orthogneiss are everywhere delineated by up to $50 \mathrm{~cm}$ thick mylonites (Fig. 6d).

\subsubsection{Granulite}

Granulites occur as garnet-orthopyroxene-biotite-alkali feldspar-bearing schlieren $( \pm$ sapphirine, sillimanite, cordierite, corundum, spinel, plagioclase and quartz) within charnockites and as residual enclaves both in the charnockites and the migmatitic orthogneisses in Valle dei Vanni, Val Piana, Valle del Conco and Val Aurosina (Fig. 2). Many of the schlieren are felsic in composition (granulites type $\mathrm{E}$ and $\mathrm{F}$ in Galli et al. 2011), in which case these are identified as granulites by the presence of sapphirine or trails of orthopyroxene crystals. The residual granulites are easily distinguished by a content of mafic minerals (including sillimanite) which amounts on average to 65-75 vol\% (types A-D, Galli et al. 2011). The schlieren are up to one meter long, while the residual granulites are typically less than one meter in outcrops, but loose blocks in the Cordera river measure up to 2 cubic meters. The granulite facies peak assemblage is constituted by garnet, orthopyroxene, Ti-rich biotite \pm sapphirine \pm sillimanite \pm quartz \pm alkali feldspar \pm plagioclase and is commonly overprinted by cordierite-bearing coronae and symplectites. Thermobarometric calculations, P-T pseudosections and orthopyroxene $\mathrm{Al}$ content, show that both charnockites and granulites equilibrated at metamorphic peak conditions of $T=920-940{ }^{\circ} \mathrm{C}$ and $P=8.5-9.5$ kbar. Peak assemblages were subsequently overprinted by intergrowth, symplectite and corona textures involving orthopyroxene, sapphirine, cordierite and spinel at $T=720-740{ }^{\circ} \mathrm{C}$ and $P=7-7.5 \mathrm{kbar}$ (Galli et al. 2011).

\subsubsection{Websterite to gabbronorite}

Up to $50 \mathrm{~m}$-sized lenses of websterite to gabbronorite occur within biotite-orthogneisses, often associated with charnockites, or directly in charnockites (Figs. 2, 3). All websterite/gabbronorite lenses (enhanced with a black 8-pointed star in Fig. 2) are found within a km-wide zone reaching from Val Scarione in the west to Pizzo dei Vanni 

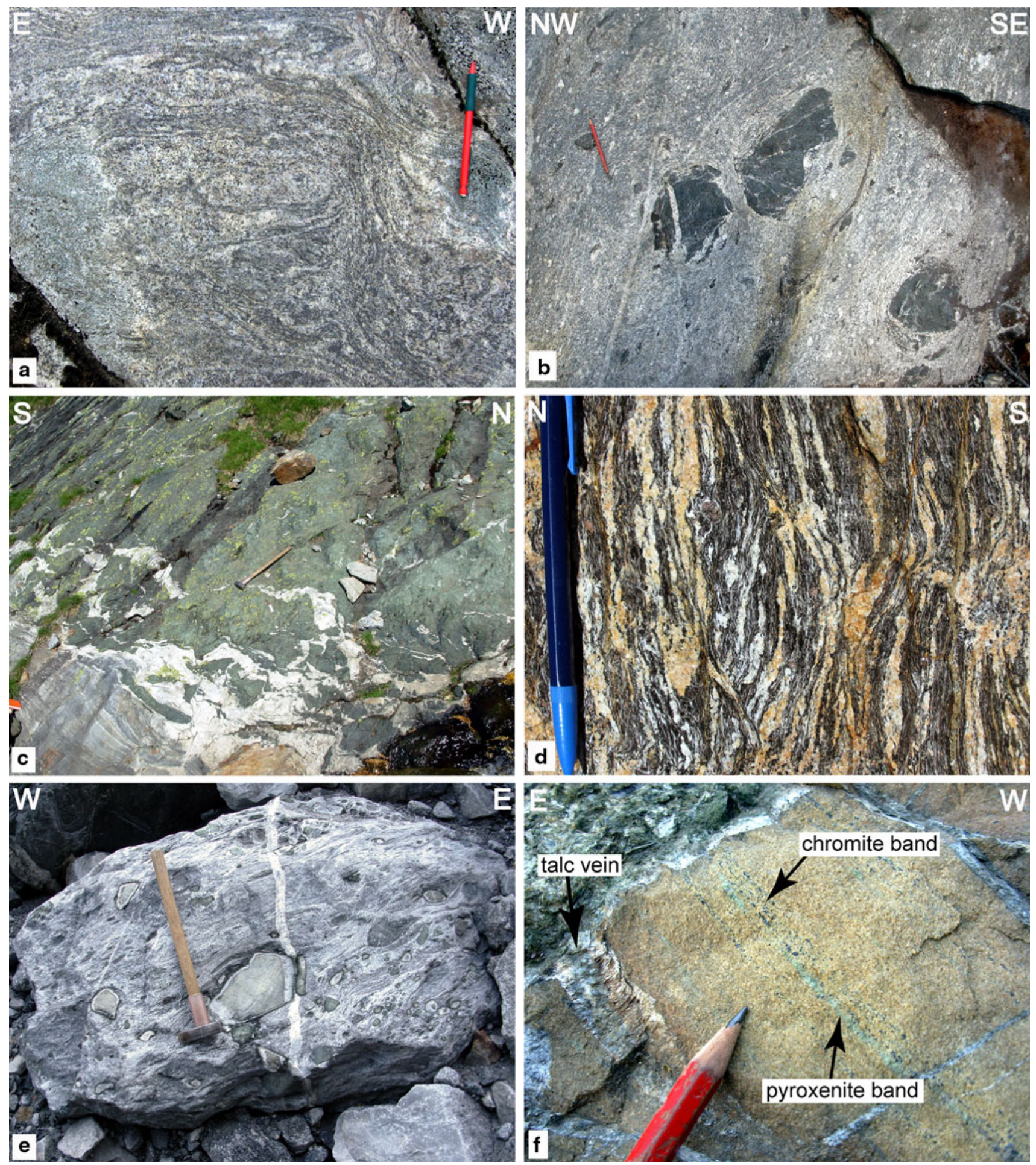

Fig. 5 Field aspect of principal rock types in the Gruf complex. a Typical migmatitic structure of the biotite-orthogneiss (upper Val Codera, $763^{\prime} 251 / 128^{\prime} 963$ ); b weakly foliated mafic enclaves intruded by leucocratic veins in the enclave-rich biotite-orthogneiss (upper Val Aurosina, 758'153/129'875); c leucocratic veins derived from the migmatitic orthogneiss (light-coloured, bottom left) intruding greenish websterite to gabbronorite (top, contact zone in upper Val Grosina, 758'643/127'405); d millimetre thick bands of leucocratic,

quartzo-feldspatic granoblastic leucosome and melanocratic, biotitesillimanite-garnet-rich melanosome in partially molten paragneiss and micaschist (upper Val Aurosina, 758'458/129'444); e decimetric, meta-ultramafic enclaves within migmatitic biotite-orthogneiss (loose block in Val Salubiasca, 759'479/124'986); f bands of pyroxenite and chromite within chlorite-spinel-enstatite-olivine fels crosscut by talc veins (upper Val Casnaggina, 760'342/129'718) 

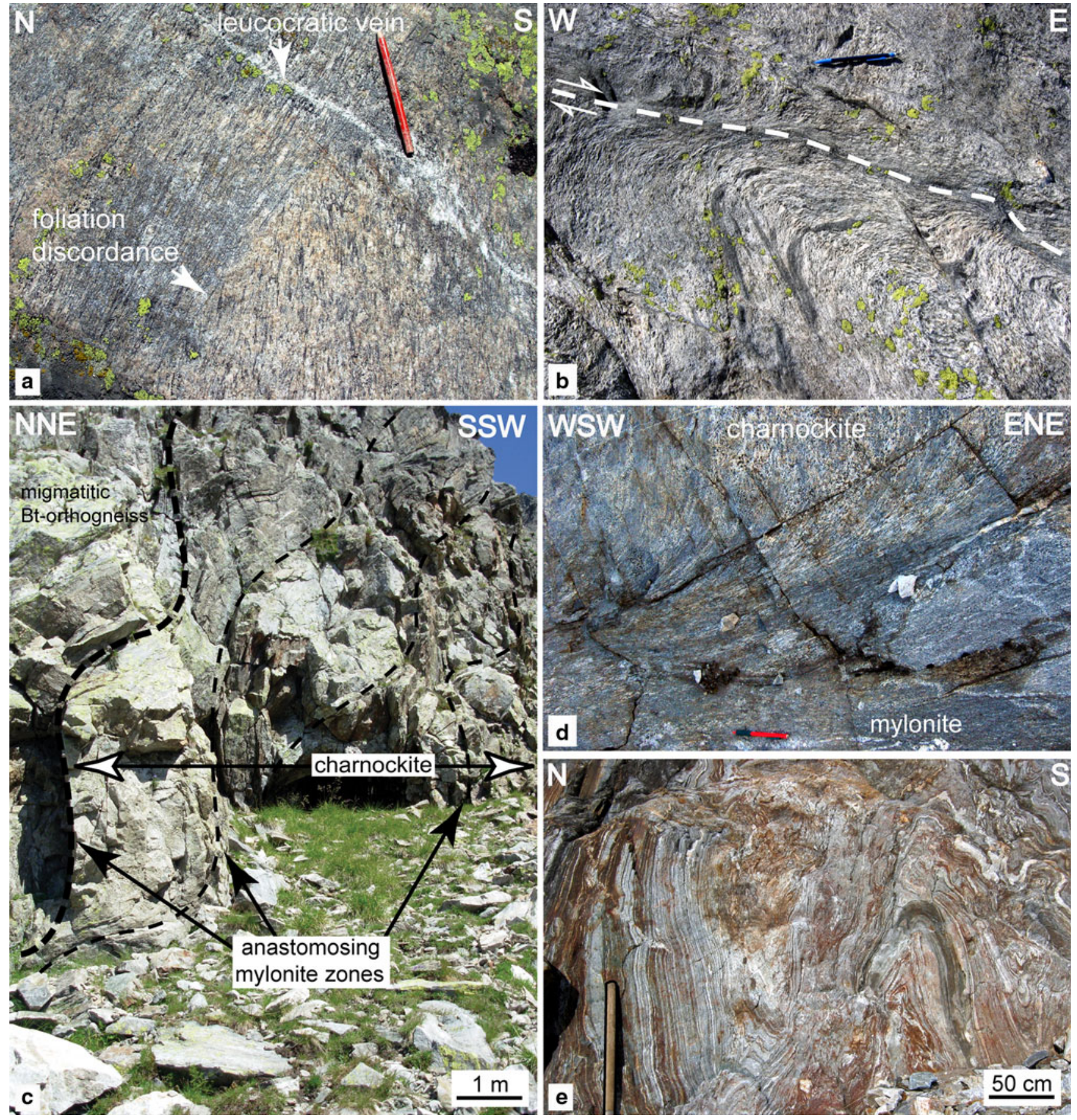

Fig. 6 Structures in the Gruf complex. a Foliation discordance, weakly foliated gneiss crosscut by more strongly foliated gneiss (arrow), formed before a crosscutting leucocratic vein (upper Val Schiesone, 755'555/127'770); b ductile shear zone (dashed line, arrows $=$ sense of shear) in the migmatitic biotite-orthogneiss (upper Val Aurosina, 758'314/128'576); c internally boudinaged charnockite with few $\mathrm{cm}$-thick, anastomosing mylonitic zones at the contact (bold

in the east. Websterites to gabbronorites exhibit a greenishbrownish colour of alteration, are massive, mid- to coarsegrained and characterised by cumulate textures. They are dashed line) with biotite-orthogneiss and between charnockitic boudins (thin dashed lines, upper Val Casnaggina, 762'644/ 130'526); d up to $50 \mathrm{~cm}$ thick mylonite of the sheared contact between charnockite and migmatitic biotite-orthogneiss (below field of view; upper Valle dei Vanni, $762^{\prime} 885 / 130^{\prime} 228$ ); e folds within partly migmatitic paragneiss and micaschist (upper Val Aurosina, $\left.758^{\prime} 049 / 129^{\prime} 817\right)$

equigranular and dominated by euhedral to subhedral, up to $1 \mathrm{~mm}$ large clinopyroxene grains. A smaller amount of slightly porphyritic orthopyroxene grains up to $4 \mathrm{~mm}$ large 


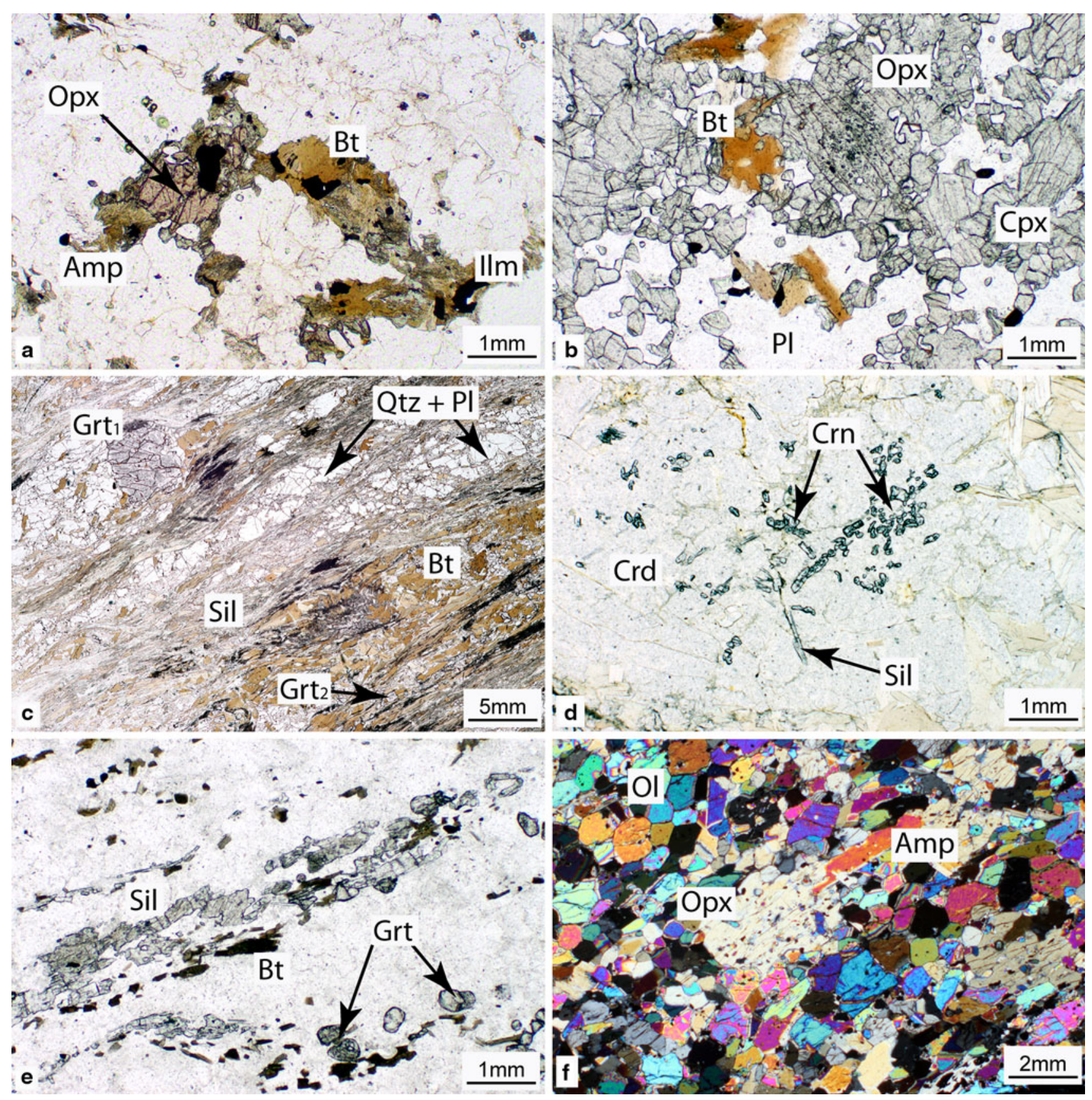

Fig. 7 Photomicrographs of principal rock types. a Orthopyroxene grains partially replaced by polymineralic coronae of amphibolebiotite-ilmenite in charnockite; b massive, equigranular texture of gabbronorite formed by clinopyroxene, orthopyroxene and interstitial polygonal plagioclase and biotite; $\mathbf{c}$ alternating granoblastic bands of quartz and plagioclase and lepidoblastic bands of biotite, sillimanite and rare muscovite in migmatitic paragneiss and micaschist. $<1 \mathrm{~cm}$ large $\mathrm{Grt}_{1}$ porphyroblast (with pressure fringes) is pre- to synfoliation; up to $1 \mathrm{~mm}$ large $\mathrm{Grt}_{2}$ overgrowing the main foliation is post-kinematic; d relictic aggregates of corundum and sillimanite surrounded by polygonal cordierite in a partly migmatitic micaschist,

is also found (Fig. 7b). Fine-grained large, polygonal plagioclase and biotite are interstitial and in textural equilibrium with the two pyroxenes. The amount of close to the contact with the Bergell intrusion, east of Bivacco Vaninetti; e detail of a fine-grained sillimanite-garnet-bearing leucogranite; f neoblastic texture of equigranular olivine grains, inclusion-rich enstatite porphyroblasts, elongated and oriented amphibole and rare chlorite and spinel in metaperidotite at Bivacco Vaninetti. Key to abbreviations: Amp amphibole, Anth anthophyllite, Bt biotite, Chl chlorite, Cpx clinopyroxene, $\mathrm{Crd}$ cordierite, $\mathrm{Crn}$ corundum, Grt garnet, Ilm ilmenite, Kfsp K-feldspar, Musc muscovite, $O l$ olivine, $O p x$ orthopyroxene, $P l$ plagioclase, $Q t z$ quartz, Sil sillimanite, $S p l$ spinel

plagioclase varies from sample to sample. In the strongly altered websterites to gabbronorites, clinopyroxene and orthopyroxene are replaced by centimetric, elongated, 
poikilitic green amphibole and aggregates of fine-grained talc, respectively. Leucosomes derived from the migmatitic biotite-orthogneiss intrude the rims of websterite to gabbronorite lenses (Fig. 5c).

\subsection{Migmatitic metasediments and other rock types contained therein}

\subsubsection{Migmatitic paragneiss and micaschist}

Amongst the partially molten paragneisses and micaschists, garnet- and garnet-cordierite-bearing sillimanite-biotite schists predominate. They alternate with less frequent quartz- and plagioclase-rich garnet-bearing paragneisses. Gradational boundaries between these two lithologies suggest alternating pelitic and psammitic layers. These rocks have a brown weathering colour and occur in two major, $10 \mathrm{~km}$ long and $1 \mathrm{~km}$ wide zones (Figs. 2, 3). Smaller lenses, $<1 \mathrm{~km}$ long, occur around Bivacco Vaninetti, in the upper part of Val Averta, and between the enclave-rich biotite-orthogneiss and the Chiavenna unit (Fig. 2). Paragneisses and micaschists are characterised by bands of milli- to centimetric, granoblastic layers and lenses of quartz, plagioclase \pm alkali feldspar \pm cordierite constituting a migmatitic leucosome. Therein, quartz grains are slightly elongated and subhedral, plagioclase is subhedral to anhedral and alkali feldspar forms subhedral perthitic grains, all typically $2 \mathrm{~mm}$ in size. Myrmekites are frequent along alkali feldspar-plagioclase boundaries; cordierite forms subhedral mm-large grains.

Millimetric, melanocratic lepidoblastic bands mainly consisting of biotite, fibrolitic sillimanite, rare muscovite, garnet and quartz \pm plagioclase \pm corundum (the latter only in the immediate vicinity to the Bergell pluton) represent the residual melanosome to mesosome (Figs. 5d, 7c). In the melano- to mesosomes, elongated and oriented, up to $2 \mathrm{~mm}$ large biotite flakes form aggregates that define the main foliation together with fibrolitic sillimanite and rare, up to $0.5 \mathrm{~mm}$ large, muscovite flakes (Fig. 7c). Garnet occupies two texturally different sites. Garnet ${ }_{1}$ forms centimetric, pre-kinematic porphyroblasts that deflect the main foliation, and is associated with pressure fringes. It displays an equant and subhedral habitus and generally has inclusion-rich cores and inclusion-free rims. Garnet ${ }_{2}$ forms up to $1 \mathrm{~mm}$, post-kinematic, rounded and subhedral grains overgrowing the main foliation (Fig. 7c). Quartz is rare and forms subhedral $<0.1 \mathrm{~mm}$ large grains. Plagioclase forms poikilitic, centimetric porphyroblasts overgrowing biotite, garnet, quartz and muscovite; it is therefore also postkinematic. Away from the contact to the Bergell pluton, there is no evidence that these metasediments have ever been exposed to higher temperature conditions than defined by the fluid-absent melting reaction of muscovite (Fig. 8).

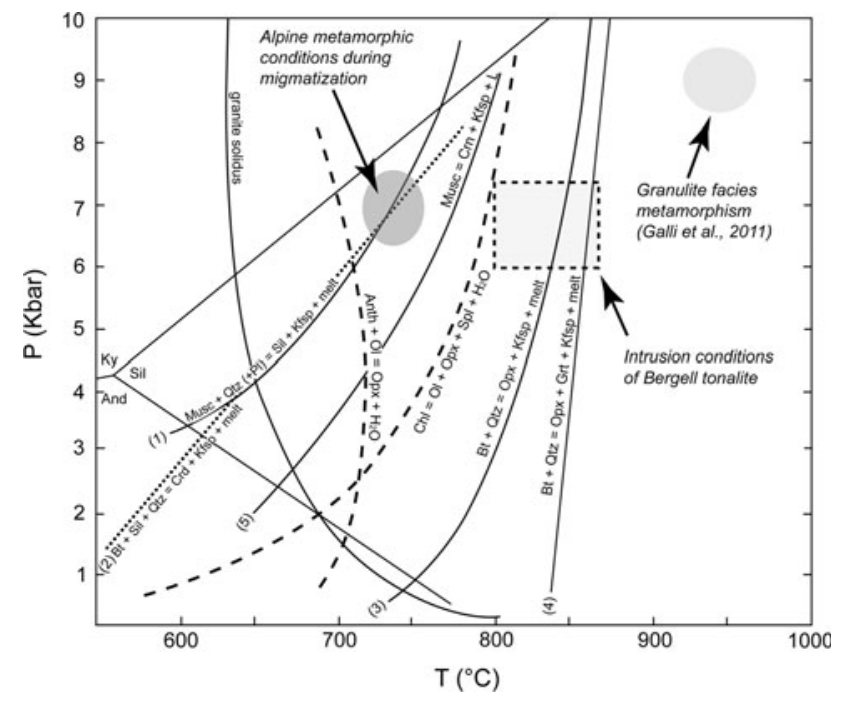

Fig. 8 Estimated metamorphic conditions (dark grey ellipse) of the Gruf migmatization. Solid lines experimentally determined reactions for the metapelitic system (references for reactions as in the text); dashed lines reaction curves for natural ultramafic bulk composition (Jenkins and Chernosky 1986; Evans and Guggenheim 1988); dotted line reaction calculated using the version 3.33 of THERMOCALC [Powell and Holland (2008); activities used in the calculation: biotite: $x(\mathrm{bt})=0.59 ; y(\mathrm{bi})=0.54 ; Q(\mathrm{bi})=0.15 ;$ cordierite: $x(\mathrm{~cd})=0.39$, $h(\mathrm{~cd})=0.1$; alkali feldspar: $\mathrm{na}(\mathrm{ksp})=0.68$; $\mathrm{ca}(\mathrm{ksp})=0.11$, abbreviations as defined by Powell and Holland (2008)]. For mineral abbreviations, see caption of Fig. 7

A granulite facies exposure similar to that experienced by the observed granulites would have led to a melt-loss from these sediments and would thus also be recognisable after potential retrogression.

Contacts between migmatitic metasediments and surrounding orthogneisses are generally marked by discrete centimetric to decimetric mylonite layers. North of Bivacco Vaninetti (Swiss coordinate $763^{\prime} 800 / 129^{\prime} 750$ ), and only there, leucosomes departing from the biotiteorthogneiss discordantly intrude the base of a large (up to $1 \mathrm{~km}$ in length) lens of migmatitic metasediments (Fig. 4).

\subsubsection{Leucogranite}

Paragneiss and micaschist are often in direct contact with fine- to coarse-grained, massive to slightly foliated leucogranites (Figs. 2, 3) composed of quartz, plagioclase, alkali feldspar, biotite, muscovite \pm garnet \pm sillimanite; apatite, chlorite, sphene, rutile, ilmenite and zircon are accessory minerals. Rounded, subhedral to anhedral, up to $0.2 \mathrm{~mm}$ large quartz, plagioclase and perthitic alkali feldspar grains define an equigranular-interlobate texture. Biotite and muscovite are elongated, well oriented, up to $1 \mathrm{~mm}$ long, forming elongated flakes parallel to the main foliation. Garnet is present as rounded, xenomorphic, up to $0.3 \mathrm{~mm}$ large blasts. Millimetric garnet grains are generally 
more abundant in the finer-grained leucogranite (Fig. 7e), in particular between San Cassiano in Valle della Mera and Corna di Garzone to the east-northeast (Fig. 2). Sillimanite forms up to $1 \mathrm{~mm}$ long, prismatic grains within the main foliation. Commonly, prismatic sillimanite exhibits coronae of fine-grained muscovite. Leucogranites show intrusive, sharp and irregular contacts with the migmatitic paragneisses and micaschists. Conversely, contacts with the migmatitic biotite-orthogneiss are diffuse and marked by the progressive disappearance of biotite and concomitant appearance of both muscovite and garnet in the leucogranite.

\subsubsection{Augengneiss}

Up to $20 \mathrm{~m}$ thick sheets of augengneiss are intercalated with the paragneisses and micaschists east of Bivacco Vaninetti and on the western flank of Cima di Droso (Figs. 2, 4). The augengneiss is coarse-grained, weakly foliated and displays an equigranular-interlobate texture formed by subhedral quartz, plagioclase and alkali feldspar and by almost non-oriented biotite and muscovite flakes. Granular, biotite-free leucocratic dykes cut the weak augengneiss foliation or occur within centimetric ductile shear zones. Intrusive and discordant contacts of the augengneiss into the metasedimentary sequence are locally preserved.

\subsection{Lithologies contained both within metagranitoids and metasediments}

\subsubsection{Chlorite-spinel-enstatite-olivine fels}

Up to $500 \mathrm{~m}$ large lenses of chlorite-spinel-enstatite-olivine fels in contact with metasediments and leucogranites occur around Bivacco Vaninetti, south of Alpe Spluga and between Val Piana and Valle del Conco (Figs. 2, 4). Smaller lenses $(<5 \mathrm{~m}$ in size $)$ of the same rock type occur also in Val Piana, to the south of Corna di Droso and at the basis of Valle dell'Orco as clusters of enclaves in the migmatitic biotite-orthogneiss (Fig. 5e). These meta-peridotites weather to an intense orange-brown colour and exhibit alternating and sometimes isoclinally folded lherzolite, dunite, pyroxenite and chromite bands (Fig. 5f). The rock has an equigranular, neoblastic texture constituted of olivine, less frequent enstatite and chlorite and rare tremolite (Fig. 7f). Grain boundaries are straight, suggesting textural equilibrium. Olivine occurs as anhedral, up to $0.2 \mathrm{~mm}$ large grains, often partly replaced by aggregates of acicular serpentine. Enstatite forms elongated, up to $2 \mathrm{~mm}$ large porphyroblasts showing undulose extinction and a slightly preferred shape orientation. Generally, enstatite contains many tiny inclusions of talc, spinel and magnetite and may be replaced by fine-grained talc. Up to $0.4 \mathrm{~mm}$ large chlorite and tremolite are parallel to the main foliation (Fig. 7f). Spinel is present in greenish to brownish, fine $(<0.1 \mathrm{~mm})$, rounded grains or as green spinel-magnetite lamellar aggregates surrounded by chlorite. Chloritespinel-enstatite-olivine fels displays a pronounced foliation mostly defined by enstatite and amphibole. This foliation overgrows the compositional banding and is generally not parallel to the regional foliation.

Within the large lenses around Bivacco Vaninetti, several meter-thick meta-rodingite dykes mainly composed of garnet, epidote, clinopyroxene, hornblende and sphene, as well as one ferrogabbro dyke were observed to discordantly cut the banding in the metaperidotites. Numerous light greyish veins of talc, chlorite and rare titano-clinohumite mostly cut the main foliation. Contacts to the migmatitic paragneisses and micaschists are concordant and sub-mylonitic. Leucosomes from the biotite-orthogneisses are intrusive, with decimetric leucocratic veins intruding fractures at the rim of ultramafic lenses and related metabasic rocks (insets 4 and 5 in Fig. 9). Different stages of brecciation are observed: (i) angular, up to $1.5 \mathrm{~m}$ large, matching blocks, separated by thin centimetric granitic veins (inset 4 in Fig. 9); (ii) more disconnected, centi- to decimetric, rounded enclaves separated by up to $20-30 \mathrm{~cm}$ thick leucosomes (inset 5 in Fig. 9), (iii) isolated, subellipsoidal enclaves within the migmatitic biotite-orthogneisses (Fig. 5e, inset 6 in Fig. 9) and (iv) swarms of enclaves embedded and brecciated by the migmatitic biotite-orthogneiss, particularly concentrated close to Alpe Sivigia, forming what is referred to as the "Sivigia-Zug" (Wenk and Cornelius 1977, see Figs. 2, 3 profile F). In general, the ultramafic and mafic components of these breccias develop polymineralic reaction rims of talcchlorite-actinolite-hornblende-biotite and green amphibole, respectively; the granitic matrix displays centimetric crystals of labradorite in the vicinity of these enclaves.

\subsubsection{Amphibolite}

Regularly boudinaged, up to $20 \mathrm{~m}$ thick bands of amphibolites are associated with the metaperidotite lenses around Bivacco Vaninetti, between Val Piana and Valle del Conco, south of Alpe Spluga and Alpe Rossaccio, near Corna di Droso; they also occur along the contact between the Gruf complex and the Bergell intrusion (Figs. 2, 3, 4). Elongated, millimetric amphibole, euhedral plagioclase, biotite flakes and rare, subhedral clinopyroxene grains form a nematoblastic, equigranular texture. Chlorite, sphene, rutile and ilmenite are accessory minerals. Locally, amphibolites display centimetric, discordant and amphibolebearing pockets of leucosome. Accordingly, these leucosomes appear to be derived from in situ partial melting of the amphibolites. These leucosomes are in sharp contrast to 


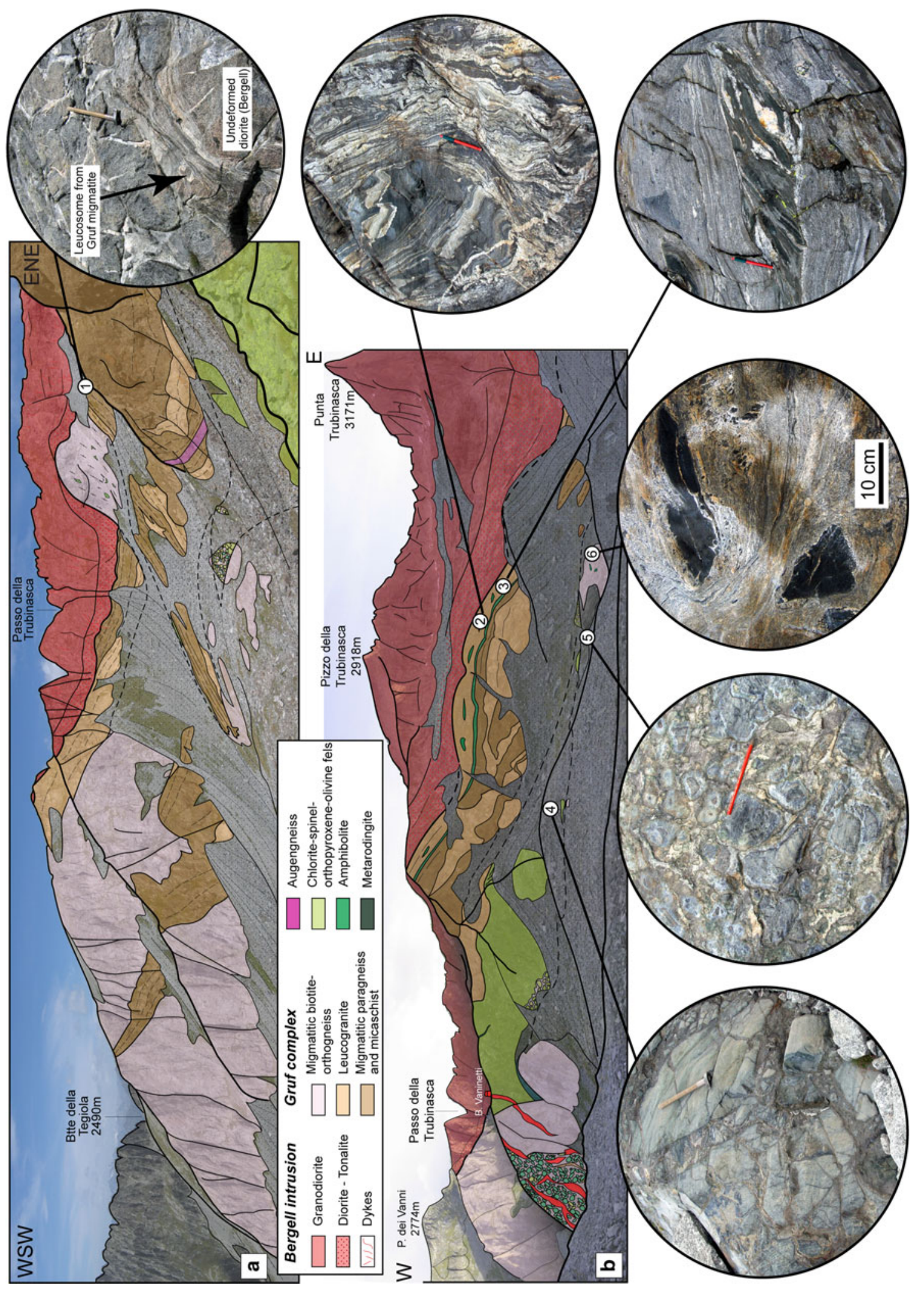

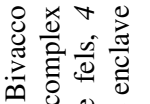

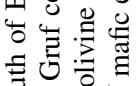

o

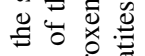

ㅇํㄹ

实

子

这若

4.

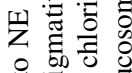

$\checkmark$ हี

골

을

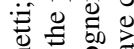

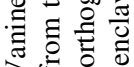

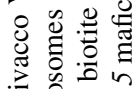

की

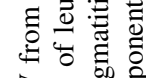

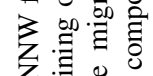

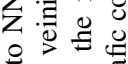

วै

츨

ज्ञ

응

등

के

है छ

응

氙焉

$\exists \therefore$.

ธี ซู

氖㻤.

ఏ

牙?

ஸे

o웅용

늘 䒕

3 ए

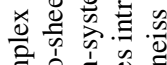

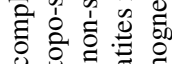

政

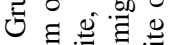

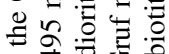

원

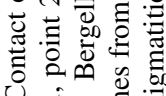

○ :

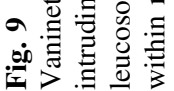


Table 1 Representative bulk compositions of rocks from the Gruf complex (see Fig. 2)

\begin{tabular}{|c|c|c|c|c|c|c|c|c|c|c|c|c|}
\hline \multirow{2}{*}{$\begin{array}{l}\text { Rock } \\
\text { type } \\
\text { Sample } \\
\text { Location }\end{array}$} & \multicolumn{3}{|c|}{ Migmatitic bt-orthogneiss } & \multicolumn{2}{|c|}{$\begin{array}{l}\text { Enclave-rich } \\
\text { bt-orthogneiss }\end{array}$} & \multicolumn{3}{|c|}{ Charnockite } & \multicolumn{3}{|c|}{ Leucogranite } & \multirow{2}{*}{$\begin{array}{l}\text { Augengneiss } \\
\text { HvOG2 } \\
\text { Biv. } \\
\text { Vaninetti }\end{array}$} \\
\hline & $\begin{array}{l}\text { Or6 } \\
\text { Val } \\
\text { Scarione }\end{array}$ & $\begin{array}{l}\text { TeGrl } \\
\text { Val } \\
\text { Casnaggina }\end{array}$ & $\begin{array}{l}\text { HvGrl3 } \\
\text { Biv. } \\
\text { Vaninetti }\end{array}$ & $\begin{array}{l}\text { DLOG1 } \\
\text { Val } \\
\text { Bondasca }\end{array}$ & $\begin{array}{l}\text { Scl3 } \\
\text { Val } \\
\text { Schiesone }\end{array}$ & $\begin{array}{l}\text { PeCh6 } \\
\text { Val } \\
\text { Vertura }\end{array}$ & $\begin{array}{l}\text { BoGrl } \\
\text { Val } \\
\text { Bondasca }\end{array}$ & $\begin{array}{l}\text { Conc14 } \\
\text { Valle del } \\
\text { Conco }\end{array}$ & $\begin{array}{l}\text { HvOG3 } \\
\text { Biv. } \\
\text { Vaninetti }\end{array}$ & $\begin{array}{l}\text { Pial } \\
\text { Val } \\
\text { Piana }\end{array}$ & $\begin{array}{l}\text { RoGr3 } \\
\text { Val } \\
\text { Vertura }\end{array}$ & \\
\hline $\mathrm{SiO}_{2}$ & 65.21 & 64.16 & 68.36 & 67.47 & 66.45 & 68.579 & 64.94 & 72.76 & 73.68 & 74.04 & 71.05 & 69.02 \\
\hline $\mathrm{TiO}_{2}$ & 0.61 & 0.72 & 0.45 & 0.48 & 0.58 & 0.529 & 0.68 & 0.34 & 0.18 & 0.18 & 0.34 & 0.68 \\
\hline $\mathrm{A}_{2} \mathrm{O}_{3}$ & 16.46 & 16.58 & 15.85 & 16.01 & 15.98 & 15.510 & 16.24 & 14.71 & 14.38 & 13.96 & 14.82 & 14.54 \\
\hline $\mathrm{FeO} *$ & 4.48 & 5.09 & 3.48 & 3.54 & 4.12 & 4.695 & 4.83 & 2.82 & 1.59 & 1.56 & 2.24 & 4.00 \\
\hline $\mathrm{MnO}$ & 0.07 & 0.09 & 0.06 & 0.05 & 0.06 & 0.096 & 0.08 & 0.03 & 0.03 & 0.04 & 0.02 & 0.05 \\
\hline $\mathrm{MgO}$ & 1.50 & 1.37 & 0.85 & 0.91 & 1.03 & 1.870 & 2.17 & 0.72 & 0.32 & 0.33 & 0.69 & 1.11 \\
\hline $\mathrm{CaO}$ & 3.61 & 3.70 & 3.07 & 3.26 & 3.02 & 2.964 & 4.36 & 2.78 & 0.81 & 0.97 & 1.12 & 1.93 \\
\hline $\mathrm{Na}_{2} \mathrm{O}$ & 3.82 & 4.43 & 3.62 & 3.60 & 3.77 & 3.246 & 3.85 & 3.01 & 2.78 & 3.21 & 3.15 & 3.33 \\
\hline $\mathrm{K}_{2} \mathrm{O}$ & 3.21 & 2.48 & 3.52 & 3.55 & 3.52 & 2.827 & 2.20 & 2.30 & 5.05 & 4.85 & 5.13 & 4.22 \\
\hline $\mathrm{P}_{2} \mathrm{O}_{5}$ & 0.23 & 0.26 & 0.15 & 0.16 & 0.27 & 0.152 & 0.21 & 0.09 & 0.21 & 0.18 & 0.15 & 0.24 \\
\hline $\mathrm{Cr}_{2} \mathrm{O}_{3}$ & 0.00 & 0.00 & 0.00 & 0.00 & 0.00 & 0.005 & 0.00 & 0.00 & 0.00 & 0.00 & 0.00 & 0.00 \\
\hline $\mathrm{H}_{2} \mathrm{O}$ & 0.47 & 0.49 & 0.39 & 0.49 & 0.62 & 0.314 & 0.58 & 0.29 & 0.89 & 0.59 & 0.70 & 0.59 \\
\hline Total & 99.69 & 99.37 & 99.79 & 99.51 & 99.42 & 100.79 & 100.14 & 99.86 & 99.92 & 99.92 & 99.41 & 99.72 \\
\hline A/CNK & 1.01 & 0.99 & 1.03 & 1.02 & 1.03 & 1.12 & 0.98 & 1.18 & 1.25 & 1.14 & 1.16 & 1.07 \\
\hline $\mathrm{x}(\mathrm{Mg})$ & 0.37 & 0.32 & 0.30 & 0.31 & 0.31 & 0.41 & 0.44 & 0.31 & 0.26 & 0.27 & 0.35 & 0.33 \\
\hline
\end{tabular}

The complete geochemical database is presented in Online Resource 1

* Total iron as FeO. $\mathrm{H}_{2} \mathrm{O}$ content estimated from Loss of Ignition (LOI); A/CNK $=\mathrm{Al}_{2} \mathrm{O}_{3} /\left(\mathrm{CaO}+\mathrm{Na}_{2} \mathrm{O}+\mathrm{K}_{2} \mathrm{O}\right)\left(\mathrm{molar}\right.$ ratio); $\mathrm{X}_{\mathrm{Mg}}=\mathrm{MgO} /$ $(\mathrm{MgO}+\mathrm{FeO})$

granite or sediment derived leucosomes that never bear amphibole. Due to their scarceness and maximal thickness of $2 \mathrm{~cm}$, they have not been analysed and their presumably trondhjemitic chemistry (Winther and Newton 1991) could not be verified.

The orientation of amphibole and biotite defines a welldeveloped foliation. In places, several centimetre thick mylonites mark the contact with the country rock. East of Bivacco Vaninetti, close to the Bergell intrusion, leucosomes from migmatitic paragneisses and micaschists cut the amphibolite bands and foliation, isolating amphibolite enclaves in leucosomes (inset 2 in Fig. 9).

\subsubsection{Calc-silicate}

Rare calc-silicates, associated with metaperidotites and amphibolites, form up to $20 \times 1 \mathrm{~m}$ boudins south of Alpe Rossaccio and all along the contact between the Gruf complex and the Bergell tonalite. These lenses also form xenoliths within the Bergell tonalite (Fig. 2). Calcsilicates are coarse-grained and foliated and are constituted by alternating garnet-, epidote-, diopside-, calcite- and quartzrich layers. Vesuvianite, spinel, sphene, wollastonite, brucite and green amphibole occur in minor amounts. Scapolite has been reported (Trommsdorff 1966; Oterdoom 1980) but has not been identified during this study.

\section{Whole rock geochemistry}

Sixty samples of typical rock types from the Gruf complex were analysed for major and trace elements: biotite-orthogneisses (18 migmatitic biotite-orthogneisses and 6 enclaverich biotite-orthogneisses), leucogranites (23 samples), charnockites ( 3 garnet-sillimanite-absent samples, 6 garnetbearing, sillimanite-absent samples and 2 garnet-sillimanitebearing samples) and augengneisses ( 2 samples). Bulk rock data were obtained using a Panalytical Axios wavelength dispersive XRF spectrometer (WDXRF, $2.4 \mathrm{kV}$ ) at ETH Zurich. Representative bulk rock compositions are given in Table 1. The complete geochemical data are presented in Online Resource 1.

Geochemically, the metagranitoids can be divided into two compositional groups. One comprises the migmatitic biotite-orthogneiss, the enclave-rich biotite-orthogneiss, the garnet-sillimanite-free charnockites and the augengneisses. The second group is formed by more $\mathrm{SiO}_{2}$-rich and more peraluminous leucogranites together with the garnet-sillimanite-bearing charnockites.

The rocks of the first group display $\mathrm{SiO}_{2}$ contents between 59 and $70.5 \mathrm{wt} \%$. Compared to the second group they are relatively poor in $\mathrm{K}_{2} \mathrm{O}(1.51-3.85 \mathrm{wt} \%)$ but rich in $\mathrm{Al}_{2} \mathrm{O}_{3}$ (14.54-18.87 wt \%), $\mathrm{FeO}$ (2.24-6.68 wt\%), $\mathrm{MgO}$ (0.66-3.39 wt\%), $\mathrm{CaO}(2.22-4.78 \mathrm{wt} \%)$, and $\mathrm{TiO}_{2}(0.29$ 

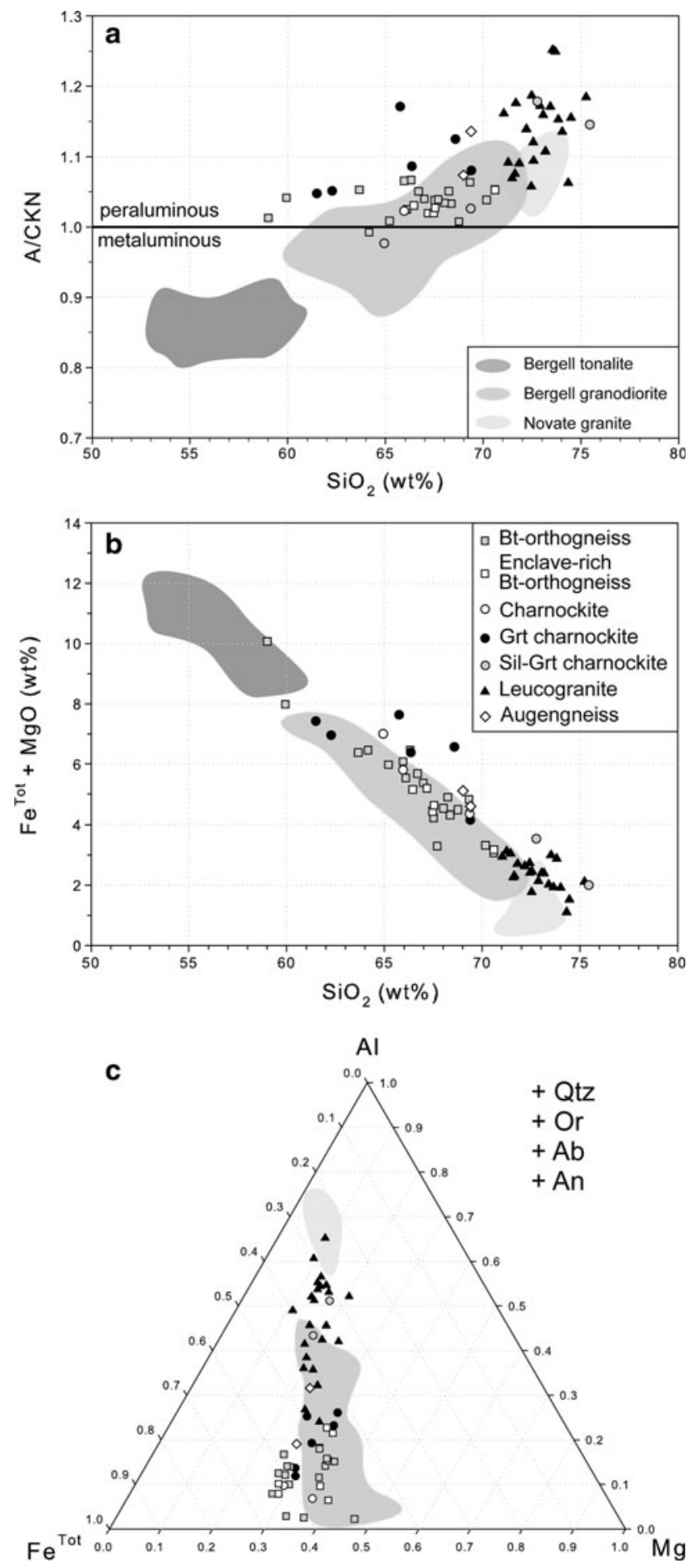

Fig. 10 a $\mathrm{A} / \mathrm{CKN}$ moles vs. $\mathrm{SiO}_{2}(\mathrm{wt} \%)$ diagram, b $\mathrm{FeO}^{\mathrm{Tot}}+\mathrm{MgO}$ (wt $\%$ ) vs. $\mathrm{SiO}_{2}$ (wt \%) diagram, c AFM diagram (moles) projected from quartz and feldspar components. Compositional fields of the calcalkaline Bergell tonalite and granodiorite and the S-type Novate granite after Moticska (1970), Wenk et al. (1977) and Reusser (1987a, b). The Bergell tonalite field with negative Al-coordinates is not shown in $\mathbf{c}$

$0.94 \mathrm{wt} \%)$. Generally, the rocks of the first group are only slightly peraluminous (Fig. 10a). Garnet-bearing charnockites (A/CKN: 1.05-1.17) and augengneisses (A/CKN:
1.07-1.14) have slightly higher alumina saturation values than the biotite-orthogneisses (A/CKN: 0.99-1.07) and garnet-sillimanite-absent charnockites (A/CKN: 0.98-1.03), in accordance with the occurrence of garnet in these charnockites and muscovite in the augengneisses.

The second group is considerably richer in $\mathrm{SiO}_{2}$ (71-75.3 wt \%) and $\mathrm{K}_{2} \mathrm{O}(2.04-6.16 \mathrm{wt} \%)$ but poorer in $\mathrm{Al}_{2} \mathrm{O}_{3}$ (13.35-15.42 wt\%), $\mathrm{FeO}(0.94-2.82 \mathrm{wt} \%), \mathrm{MgO}$ $(0.15-2.32 \mathrm{wt} \%), \quad \mathrm{CaO}(0.46-2.78 \mathrm{wt} \%)$, and $\mathrm{TiO}_{2}$ $(0.06-0.34 \mathrm{wt} \%)$. Hence, the second group is significantly more peraluminous $(\mathrm{A} / \mathrm{CKN}$ : $1.06-1.35)$ compared to the first group (Fig. 10a). This is in agreement with the higher amount of muscovite + garnet \pm sillimanite within leucogranites, and garnet + sillimanite within charnockites belonging to this second group.

In $\mathrm{Fe}^{\text {tot }}+\mathrm{MgO}$ vs. $\mathrm{SiO}_{2}$ (wt\%) space, all samples together form an array with a strong negative correlation (Fig. 10b). The samples of the first group are relatively poorer in silica but richer in $\mathrm{FeO}$ and $\mathrm{MgO}$ compared to those of the second group. The same two compositional groups are also well discernable in an AFM ternary projected from the quartzo-feldspatic components (Fig. 10c). The rocks of the first group plot towards the $\mathrm{Fe}-\mathrm{Mg}$ rich side, while the rocks of the second group are closer to the Al-apex. In summary, the second group of granitoids is more peraluminous while the first group is more granodioritic in composition.

\section{Structural description of the Gruf complex}

\subsection{Orientation data and geometry of the main structures}

The regional structure of the Gruf complex is dominated by ENE-WSW trending, steeply inclined lithological contacts and very roughly parallel main foliations (Figs. 2, 3, 11). The foliations predominantly dip to the NNW in the northern and central parts of the Gruf complex but prevalently to the SSE in the southern part (Fig. 11). These divergent attitudes have been interpreted as two flanks of an antiformal structure within the Gruf complex (Rosenberg et al. 1995 and Schmid et al. 1996a, b). A different geometry is observed between Sivigia and Bivacco Vaninetti, where the main foliation in biotite-orthogneisses changes within less than $100 \mathrm{~m}$ from the usual ENE-WSW strike to a NNW-SSE strike, parallel to the contact with the approximately $150 \mathrm{~m}$ large cluster of metaperidotite lenses and parallel to the base of the Bergell pluton (Fig. 4). Such deflections of the main foliation to a NNW-SSE strike generally occur near and at the contacts with other ultramafic lenses, around the charnockites, and near and in the Bergell tonalite (Fig. 4). Since NNW-SSE oriented foliations have the same mineral characteristics as the regional 
ENE-WSW foliations, and owing to map continuity from one direction to the other, these deflections denote local wrapping of the migmatitic foliation around boudinaged and enclave-forming rocks of higher competence. Orientation differences do not adhere to a large scale trend and do not delineate a regional fold that would fold the earlier main foliation (Figs. 4, 11, 12). In fact, the changes in orientations are scattered on a map; if they were marking a hinge zone, they would align along the trace of the related axial plane. A large scale fold would further imply a systematic change of asymmetric Z/S parasitic folds from one limb to the other, and $\mathrm{M}$ folds in between, none of which is observed. We conclude that the curved contact of the Bergell contact on maps is a primary intrusive feature of the originally arched plutonic shape (the "synmagmatic folding" of Davidson et al. 1996).

Large lenses consisting of charnockite display a distinct internal foliation which, compared to the country rock, diverges from the usual orientation, apparently jumbled, without a clear regional trend (Fig. 11). Metaperidotite lenses enclosed within migmatitic metasediments are also strongly foliated. However, their internal foliation is distinct and discordant to that of the country rock, indicating that this internal foliation formed during a stage preceding the incorporation of these mantle pieces into the Gruf gneisses. The unconnected foliations in the charnockites and metaperidotites are typical for boudinage structures and hence cannot be used to infer regional structural information.

The main lineation defined by mineral elongations (Fig. 12) is regionally defined by the preferred orientation of elongated biotite flakes in the migmatitic metagranitoids and by biotite and sillimanite in the migmatitic metasediments. Predominantly, the lineations plunge $30^{\circ}-40^{\circ}$ to the $\mathrm{E}$ or $\mathrm{NE}$, but within charnockitic and ultramafic lenses, mineral lineations exhibit variable orientations (Fig. 12). Together with the foliations, these within-boudin structures reflect local strain complexities (possibly a disrupted old event).

\subsection{Intensity and style of deformation}

Whereas the orientation and geometry of the main structures are similar throughout the Gruf complex, intensity and style of deformation are markedly heterogeneous and depend on rock type and the degree of partial melting. The migmatitic biotite-orthogneisses and leucogranites are either weakly foliated or characterised by an unsystematic fabric (Fig. 5a). The main foliation is mostly a spaced migmatitic banding which is irregularly folded or contorted, reminiscent of sub-magmatic flow. This is consistent with the fact that minerals defining the regional foliation and lineation do not display features of crystalline plasticity to the level one might expect in strongly foliated rocks sometimes transient to macroscopically mylonitic textures. A dynamic, fluidal environment is also suggested by cross cutting relationships of foliations with the same mineralogical characteristics, a feature described in several plutonic and migmatitic environments (Hutton 1988; Paterson et al. 1989; Vernon 2000; Berger et al. 2008). Late leucosome veins cutting across foliations also attest for the syn- migmatitic to magmatic character of the regional foliation (Fig. 6a).

Up to $20-30 \mathrm{~cm}$ thin ductile shear zones are abundant, particularly in the upper part of Val Aurosina, Valle del Conco, Val Piana, Val Schiesone and west of Bivacco Vaninetti (Fig. 6b). The typical S shape of the foliations to both sides of the planar mylonite zones indicates that the migmatitic country rock was still fully ductile at the time of shearing, and mineral assemblages across such shear zones (e.g. recrystallised biotite, quartz and feldspars) document that shearing still took place under amphibolite facies conditions. These shear zones are commonly accompanied and intruded by relatively less sheared aplite and pegmatite dykes and leucosomes (Fig. 13a-e), indicating syn-migmatitic shearing in the presence of melt.

Three main groups of ductile shear zones have been observed. A first group strikes ENE-WSW and steeply dips towards NNW, rarely to the SSE. The associated mineral-stretching lineation plunges from $20^{\circ}$ to $80^{\circ}$ to the NNE to E; a top-to-the SW (combined reverse-sinistral) shear sense is observed (Figs. 13b, 14a). The second group displays steeply N-dipping shear zones with a stretching lineation plunging $20^{\circ}-60^{\circ}$ to the NE; sense of shear is top-to-the NE (dextral-normal) (Figs. 13b, 14b). The third group consists of NW-SE-striking shear zones, steeply dipping towards the NE and with a stretching lineation plunging $10^{\circ}-50^{\circ}$ towards ENE; sense of shear is top-to-the $\mathrm{NE}$ indicating dextral-normal movement (Fig. 14c). All three sets of shear zones carry identical mineral associations, suggesting that they developed contemporaneously. Similar shear zone patterns have been described in the Novate granite (Ciancaleoni and Marquer 2006) and in the Adula nappe (Meyre et al. 1998). Together, they describe syn- to late migmatitic and/or magmatic, dominantly top-to-the NE dextral-normal movement that documents the upward movement of the Gruf complex with respect to the northern units (Chiavenna unit and Tambo nappe).

As mentioned earlier, heterogeneous deformation within charnockite bodies is visible in arrays with a thickness of centimeters to several decimeters, in the form of anastomosing shear zones surrounding almost undeformed, meter-sized rock domains with preserved magmatic structures (e.g. schlieren or a disordered network of crosscutting melts and dykes) and in up to $50 \mathrm{~cm}$ thick mylonites at the contacts with the country rocks (Fig. 6c, d). Mylonites at the contacts of the charnockite bodies steeply dip towards 


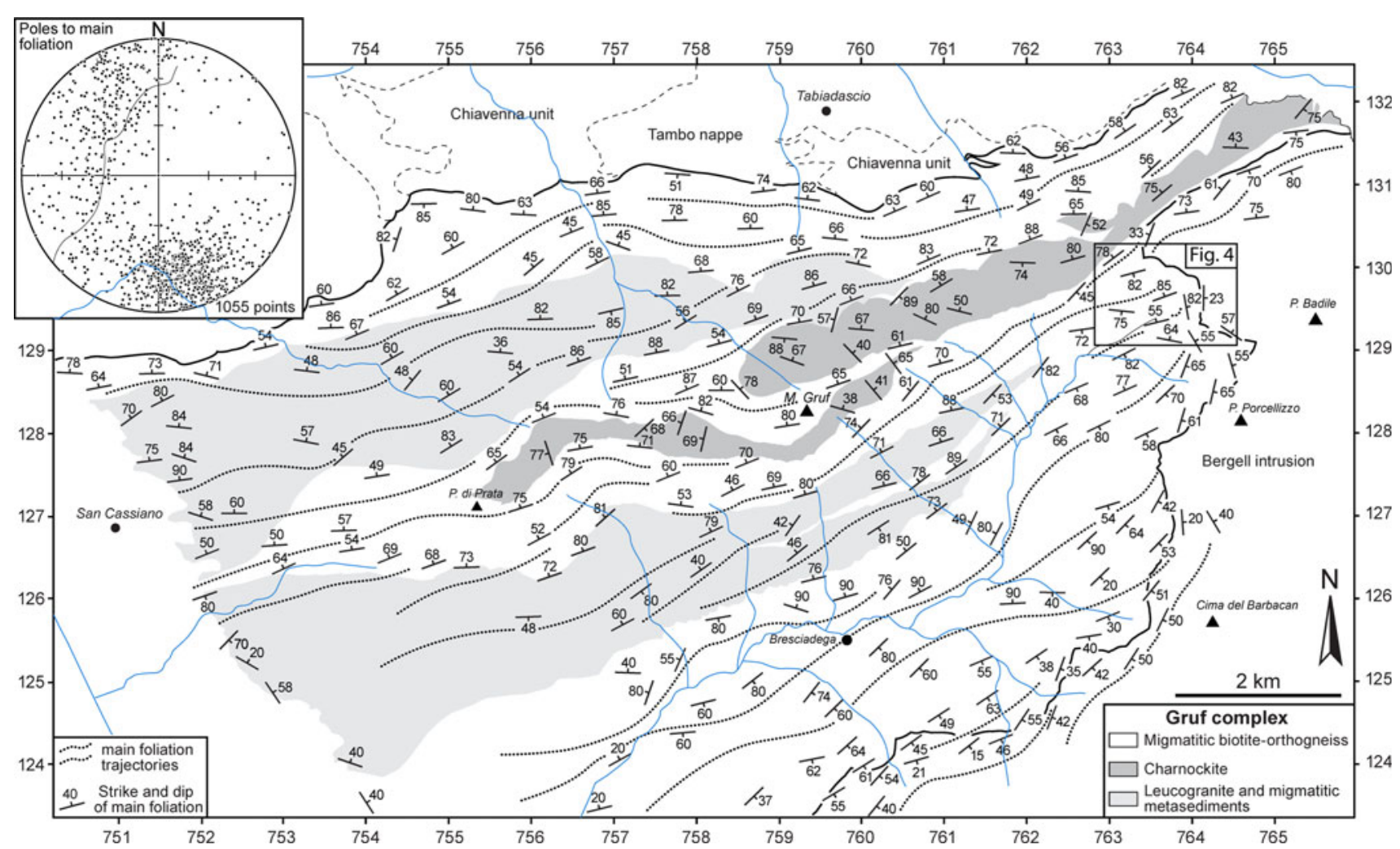

Fig. 11 Map of the orientation of the main foliation and schematic foliation trajectories in the study area (the frame of the map is identical with that of Fig. 2). Inset equal area stereoplot, lower hemisphere

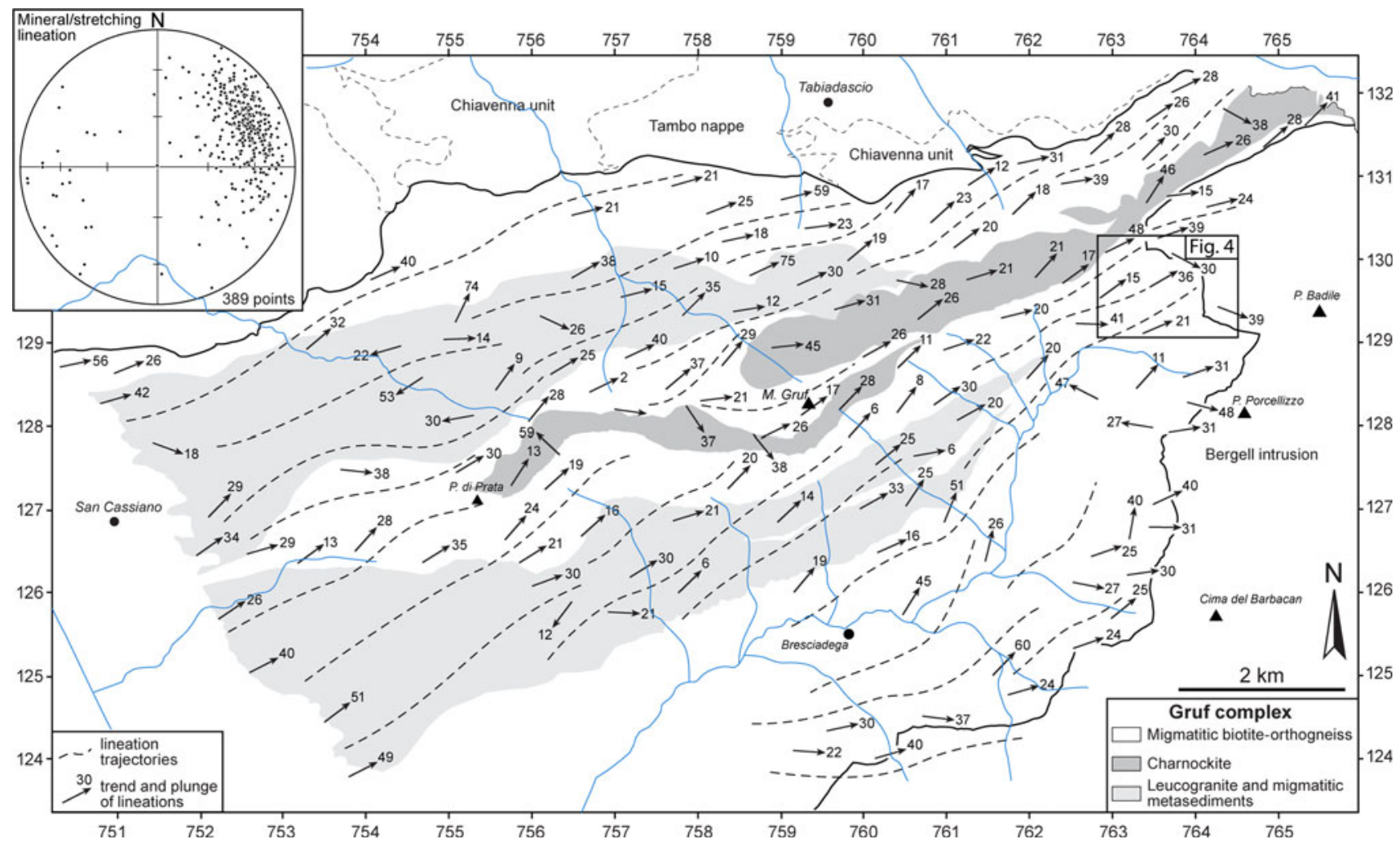

Fig. 12 Map of the orientation of the main mineral and stretching lineations and schematic lineation trend trajectories. Inset equal area stereoplot, lower hemisphere 

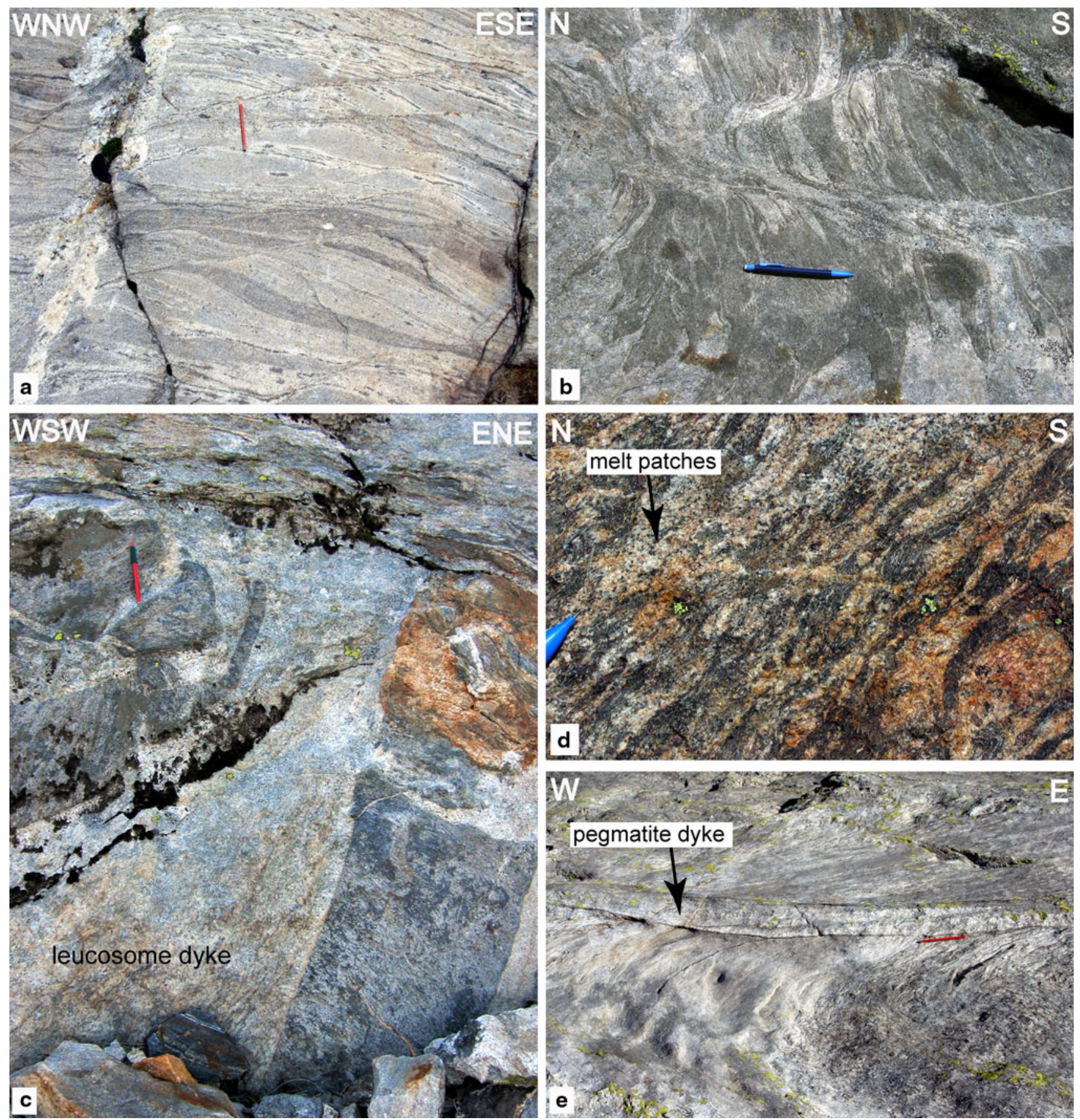

Fig. 13 a Leucosome-filled ductile shear zones within leucogranite cut by a pegmatite vein (left, running through label a). Cusp and lobate boundaries of the pegmatite indicate some flattening on the foliation of the country rock after pegmatite intrusion (east of Bivacco Vaninetti, 764'259/129'204). b Partly discordant and sheared leucosomes within conjugate shear zones (above pencil, shear zones group 1 and group 2 in the text, see Fig. 14) in migmatitic biotite-

orthogneiss (upper Val Aurosina, 757'251/128'256). c Discordant leucosome dykes within migmatitic metasediments (upper Val Casnaggina, $758^{\prime} 872 / 129^{\prime} 928$ ). d Discordant melt patches cutting the main foliation within partly migmatitic micaschist (upper Val Casnaggina, 759'580/129'545). e Partly sheared pegmatite dyke intruded into a ductile shear zone (upper Val Aurosina, 758'314/ $\left.128^{\prime} 576\right)$

the NNW and exhibit a NE plunging mineral-stretching lineation (similar to group 1 shear zones, Fig. 13), in accordance with the regional fabric outside the mylonite zones. Less sheared aplite and pegmatite dykes occur in

these mylonite zones indicating that the intrusion of these dykes was late but still syntectonic.

Partly migmatitic paragneisses, micaschists and amphibolites are characterised by a more penetrative foliation 

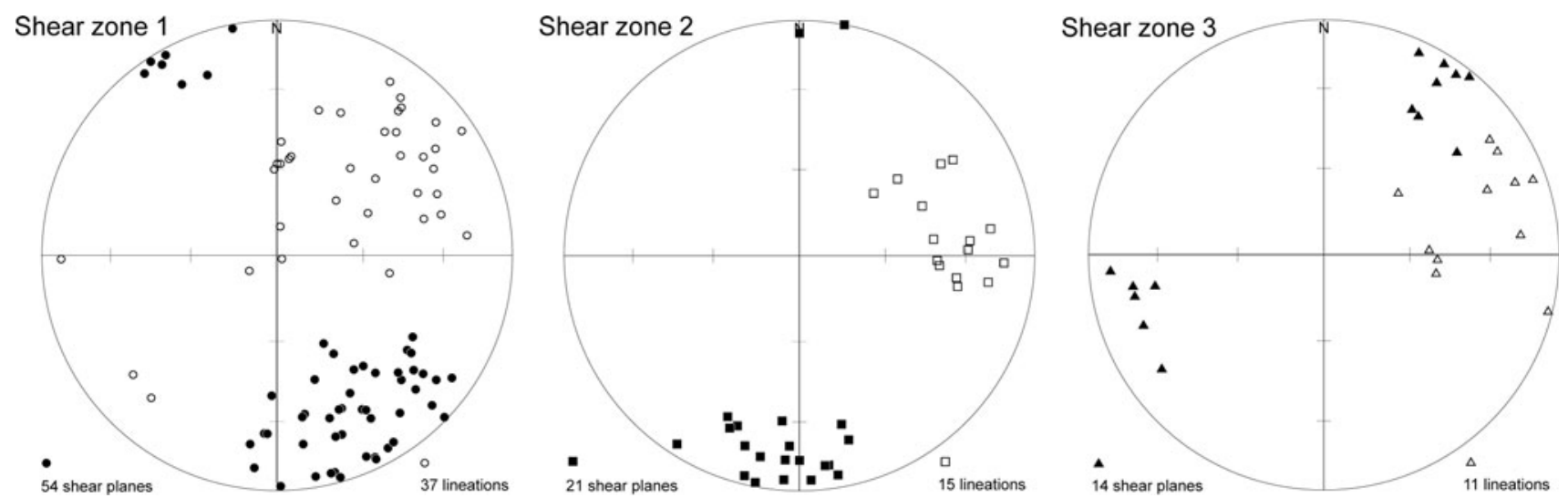

Fig. 14 Stereographic projections of poles to group 1, 2 and 3 shear zones and related stretching lineations (lower hemispheres, equal area)

and often display a more complex deformation pattern marked by complex refolding of the main foliation (Fig. 6e). Refolded folds do not display a coherent regional trend of fold axes, nor a locally coherent trend of axial planes on an outcrop-scale. This is a characteristic feature in partially molten rocks in which magmatic folds cannot be ascribed to a specific regional phase of deformation. Local crenulations associated with fold hinges fall into one and the same continuum of syn-migmatitic deformation history.

\subsection{Contact of the Gruf complex with the Chiavenna unit}

The northern contact of the Gruf complex with the Chiavenna unit is only exposed south of Prata Camportaccio, in the central part of Val Schiesone, near Alpe Prato del Conte, and around Denc dal Luf (Figs. 2, 3). The northernmost part of the Gruf complex (Fig. 15) is formed by the 200-1,200 $\mathrm{m}$ thick enclave-rich biotite-orthogneiss and a north-adjacent migmatitic biotite-schist of $<200 \mathrm{~m}$ thickness. This orthogneiss is generally massive to slightly foliated and contains up to $50 \mathrm{~cm}$ large, rounded and/or angular mafic enclaves commonly intruded by millimetric leucocratic veins (1 in Fig. 15). Locally, in particular close to its northernmost limit, the enclave-rich orthogneiss exhibits a stronger fabric and elongated enclaves (2 and 3 in Fig. 15). The main foliation strikes ENE-WSW, i.e. subparallel to the contact, and displays a NE-plunging stretching lineation with shear bands indicating a dextral and Gruf-up sense of shear. In most places where the north contact of the Gruf is exposed, a $5-10 \mathrm{~cm}$ thick mylonite zone separates the enclave-rich orthogneiss from strongly migmatitic, irregularly foliated, sillimanite-bearing ( \pm garnet, cordierite) biotite-schists. These mylonites indicate a top-to-the NE sense of shear coherent with the stretching lineation in the enclave-rich orthogneiss. The metasediments contain centimetric leucosome veins both parallel and discordant to the foliation. Along the entire Gruf-Chiavenna contact, the metasediments are associated with 10-15 m thick bands of massive, garnet-bearing leucogranites, which cut the main fabric. Furthermore, lenses of metaperidotite and amphibolite occur within the metasediments and leucogranites (Fig. 15). The contact at Denc dal Luf represents one possible but not a regionally constant lithological sequence within the northernmost lithology of the Gruf Complex. Immediately north of Denc dal Luf, the migmatitic metasediments are in contact with the metaperidotites of the Chiavenna unit. At the contact, massive leucosomes intrude strongly brecciated, serpentinized metaperidotites (4 in Fig. 15). These leucosomes are locally sheared into $<5 \mathrm{~cm}$ thick mylonites. To the north, the about $200 \mathrm{~m}$ thick Chiavenna unit forms a homogeneous mass with its characteristic orange-brownish alteration colour. Like the meta-peridotite lenses found within the Gruf complex (Sect. 3.3.1), these meta-ultramafic rock mostly consist of olivine, enstatite, chlorite and spinel; they are slightly foliated and contain meta-rodingite dykes. Still further to the north the meta-peridotites are in contact with migmatitic, regularly foliated metasediments of psammitic to pelitic composition that are attributed to the Tambo nappe.

\subsection{Contact of the Gruf complex with the Bergell intrusion}

Along the south-eastern and southern flanks of Val Codera and Val Bondasca, respectively (Fig. 2), the Gruf complex constitutes the footwall to the central part of the Bergell intrusion (Davidson et al. 1996). Most of the Bergell-Gruf contact is between tonalite and migmatitic biotite-orthogneiss (Fig. 2): the foliations in both are parallel and gently dip to the SE (Fig. 11). The 50-100 m thick, slightly foliated tonalite contains minor amounts of diorite, gabbros and hornblendites at its margin. Southeast of its tonalitic 


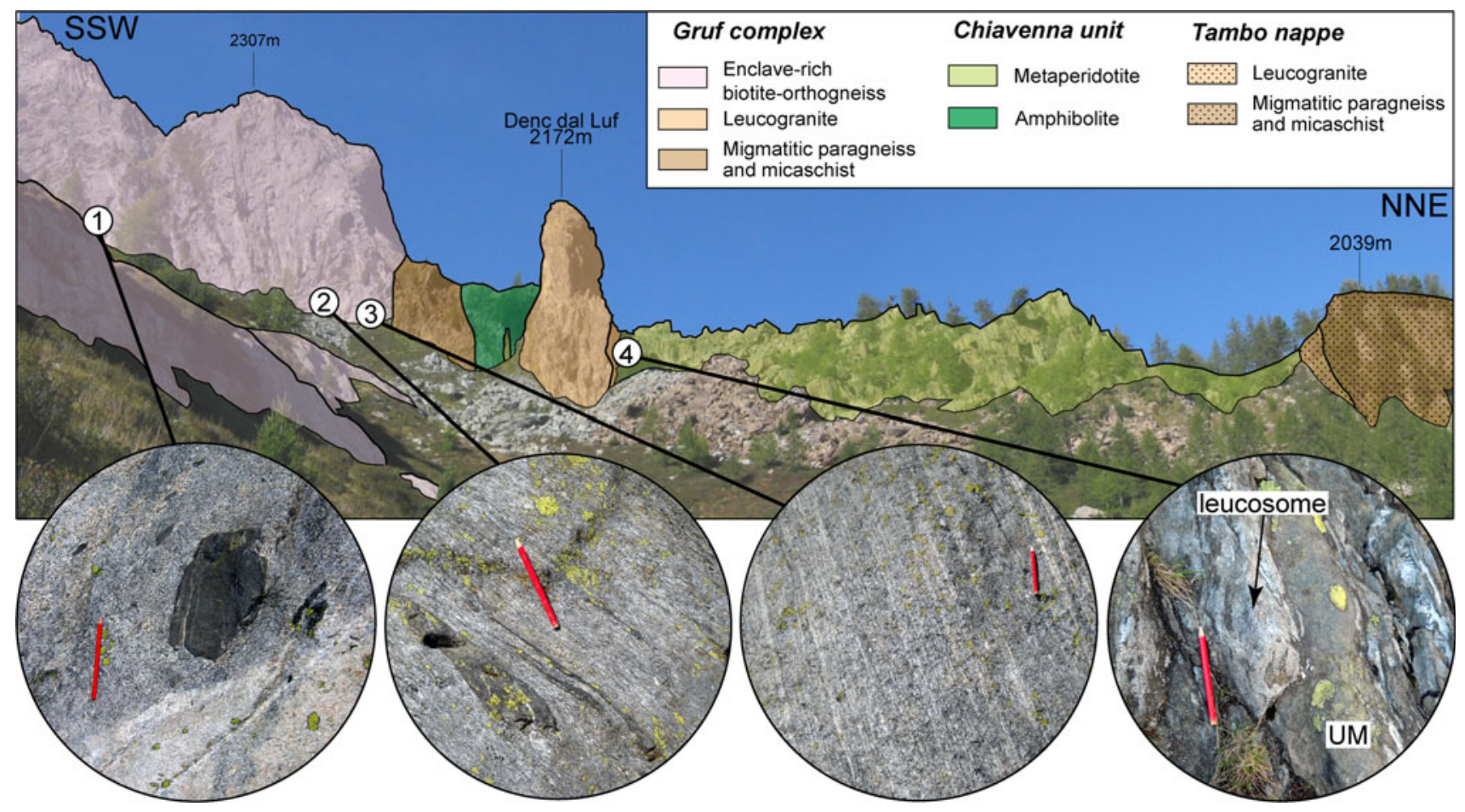

Fig. 15 Contact of Gruf complex with the Chiavenna unit along the crest of Denc dal Luf (Val Bondasca, Fig. 2). 1 Mafic enclave in weakly foliated enclave-rich biotite-orthogneiss, 2 elongated mafic

rim, the Bergell intrusion is made up of coarse-grained granodiorite with up to $10 \mathrm{~cm}$ large alkali feldspar megacrysts. An up to $150 \mathrm{~m}$ thick zone of magma mingling and mixing, often referred to as "Transitional Zone" (Moticska 1970; Wenk and Cornelius 1977), is frequently found between tonalite and granodiorite. Up to $10 \mathrm{~m}$ thick, discontinuous bands and/or meter-size lenses of dominantly calc-silicates but also of ultramafic rocks, amphibolites and metapelites preferentially occur along the Bergell-Gruf contact. These lithologies are often enclosed in the tonalite (Fig. 2) but may also occur in the adjacent migmatitic biotite-orthogneisses of the Gruf complex.

The migmatitic biotite-orthogneiss near the contact displays a stronger foliation than that of the Bergell tonalite. The contact itself often is defined by an irregular interfingering of sub-parallel leucosome veins derived from the Gruf migmatites and tonalite. This feature is commonly referred to as back-veining (Dunham 1964) and its undisturbed appearance in the field excludes any significant later deformation of the contact itself.

East of Bivacco Vaninetti (Fig. 4), the Bergell tonalite is in contact with migmatitic metasediments containing numerous basic enclaves. These migmatitic metasediments are characterised by a markedly higher content in leucosomes towards the contact and they contain centimetre-size cordierite grains and relict corundum (Fig. 7d). At the contact, the metasediments progressively pass into enclaves in foliated enclave-rich biotite-orthogneiss, 3 strongly foliated biotite-orthogneiss, 4 leucosomes from the migmatitic metasediments intrusive into Chiavenna metaperidotite (UM)

a coarse-grained fluidal leucogranite, while the numerous basic enclaves are intruded by leucogranite veins ( 2 on Fig. 9).

To the north-northeast of Bivacco Vaninetti (1 on Fig. 9), networks of up to $20-30 \mathrm{~cm}$ thick leucosome veins stemming from the Gruf metasediments discordantly intruded dark dioritic to gabbroic, as well as tonalitic rocks of the Bergell pluton. This feature suggests that brecciation near the rim to the intrusion resulted from back veining of Gruf-derived leucosomes (insert 1 in Fig. 9).

\section{Timing of and metamorphic conditions during migmatisation}

\subsection{Timing of migmatisation}

Similar orientations of foliation and lineation orientations in the Gruf complex and in the Bergell intrusion (Figs. 11, 12; Davidson et al. 1996) indicate that the major phase of deformation within the Gruf complex is of Alpine age and related to processes of partial melting and hence synmagmatic. Stromatic structures, melt-filled shear zones, veinlets, patches, pockets and dykes of leucosomes crosscutting the main foliation, as well as magmatic breccias (4 and 5 in Fig. 9, Fig. 13) and back veining of Gruf leucosomes into the Bergell pluton (1 in Fig. 9) all confirm that 
migmatisation was coeval with the main phase of deformation in the area. Syn-migmatitic recrystallisation largely reset strain and crystalline fabrics during metamorphism and melting (see also Davidson et al. 1996).

Large-scale structural investigations in the south-eastern part of the Valle della Mera showed that final emplacement and crystallisation of the Bergell pluton occurred coevally with the major regional deformation (Davidson et al. 1996). Our own observations confirm this, that partial melting in the Gruf complex occurred during final emplacement of the Bergell intrusion, which occurred from 33 to $30 \mathrm{Ma}$ (Von Blanckenburg 1992; Oberli et al. 2004). This field-based interpretation agrees with that of previous workers (e.g. Rosenberg et al. 1995; Davidson et al. 1996) and is consistent with geochronological data yielding a 34-29 Ma age range for metamorphic rims of zircon grains from granulites, charnockites, metagranitoids and leucosomes from migmatitic metasediments (Liati and Gebauer 2003; Galli et al. 2011), and additionally, with the $33 \pm 4.4$ Ma mean date from monazites contained in the Gruf granulites (Schmitz et al. 2009). The latter authors interpreted their monazite ages as the age of the granulite facies metamorphism, but Galli et al. (2012) have argued that Alpine conditions were sufficient for the resetting of monazite ages (e.g. Cherniak et al. 2004). Our interpretation is also consistent with the Oligocene age of upper amphibolite-facies metamorphism in the southern and south-eastern parts of the Lepontine dome (Hänny et al. 1975; Köppel et al. 1981; Gebauer 1996; Berger et al. 2009; Rubatto et al. 2009).

\subsection{Metamorphic conditions during migmatisation}

The occurrence of sillimanite + alkali feldspar, and the scarcity or lack of syn-kinematic muscovite, observed in most of the migmatitic micaschists of the Gruf complex suggest that partial melting was induced by fluid-absent breakdown of muscovite according to the following equation (for phase abbreviations, see caption to Fig. 7):

Musc $+\mathrm{Pl}+\mathrm{Qtz}=\mathrm{Sil}+\mathrm{Kfsp}+$ Melt

(e.g. Chatterjee and Johannes 1974; Vielzeuf and Holloway 1988) (for phase abbreviations see caption to Fig. 7). The rare still-preserved muscovite flakes observed to be oriented parallel to the main foliation in migmatitic metasediments indicate that the temperatures approached conditions of fluid-absent muscovite melting, i.e. about $700-750{ }^{\circ} \mathrm{C}$ (Fig. 8). The occurrence of sillimanite as the stable aluminosilicate limits the maximum pressure to $8 \mathrm{kbar}$ at these temperatures (Fig. 8). The reaction

$\mathrm{Bt}+\mathrm{Sil}+\mathrm{Qtz}=\mathrm{Kfsp}+\mathrm{Crd}+$ Melt

(Vielzeuf and Holloway 1988) may have produced the observed low amount of cordierite at the expense of biotite and sillimanite, at metamorphic conditions of $700-750{ }^{\circ} \mathrm{C}$ and at most 6-7 kbar(Fig. 8). Nevertheless, the lack of orthopyroxene in migmatitic metagranitoids and metasediments shows that the temperatures did reach one of the following orthopyroxeneforming, biotite dehydration melting reactions:

$$
\mathrm{Bt}+\mathrm{Qtz}=\mathrm{Opx}+\mathrm{Kfsp}+\text { Melt }
$$

or

$\mathrm{Bt}+\mathrm{Qtz}=\mathrm{Opx}+\mathrm{Grt}+\mathrm{Kfsp}+$ Melt

(e.g. Vielzeuf and Holloway 1988; Vielzeuf and Montel 1994). This constrains the maximum temperature to $<800{ }^{\circ} \mathrm{C}$ (Fig. 8). Metamorphic temperatures deduced from the mineral assemblage chlorite-spinel-orthopyroxene-olivine in the metaperidotites yield $700-770{ }^{\circ} \mathrm{C}$ (Fig. 8), coherent with the above temperatures and characteristic of uppermost amphibolite facies conditions.

The occurrence of rare, relictic corundum grains within strongly migmatitic sillimanite-alkali feldspar-garnet-cordierite-biotite schists (Fig. 7d) suggests that temperatures during contact metamorphism were at the upper end of the above range in the direct contact area with the Bergell tonalite. The reaction

Musc $=\mathrm{Kfsp}+\mathrm{Crn}+$ Melt

(e.g. Chatterjee and Johannes 1974) may account for the observed corundum and the complete consumption of muscovite in these residual peraluminous meta-sediments, indicating temperatures of $750-775{ }^{\circ} \mathrm{C}$ at the contact between the Bergell intrusion and the Gruf complex (Fig. 8). Such temperatures at the contact, a few tens of degrees higher than in the Gruf complex away from the contact are coherent with the local increase in leucosomes in the migmatitic metasediments at the contact east of Bivacco Vaninetti (2 in Fig. 9). The pressures during contact metamorphism and migmatization are expected to correspond to those reported for the Bergell tonalite based on hornblende barometry in the area around Bivacco Vaninetti (6.2 \pm 0.5 kbar; Davidson et al. 1996, their sample 92-193; see also Reusser 1987a, b). Indeed, these pressures are in perfect agreement with the 6-7 kbar pressure range we derived for the conditions during migmatization within the Gruf complex.

\section{Discussion}

Most of the previous interpretations considered the Gruf complex as a migmatitic unit that at least locally also suffered granulite-facies metamorphism during Alpine metamorphism (Droop and Bucher-Nurminen 1984; Liati and Gebauer 2003, Schmitz et al. 2009). Structurally, the Gruf complex was regarded as either the eastern continuation of the Adula nappe (Schmid et al. 1996a, b; Davidson 
et al. 1996; Frey and Ferreiro Mählmann 1999; Liati and Gebauer 2003; Berger et al. 2005) or an equivalent of the Bellinzona-Dascio zone (Wenk 1973; Wenk and Cornelius 1977; Milnes and Pfiffner 1980). This study introduces structural and petrological arguments that lead to a reinterpretation of the geological evolution of the eastern part of the Central Alps.

7.1 Charnockites and granulites vs. migmatisation: evidence for polymetamorphism within the Gruf complex

The charnockite bodies show internal structures that are separate from those of the Gruf metasediments and the rest of the orthogneisses (Fig. 11). Orthopyroxene- sapphirinebearing granulitic schlieren in the charnockites imply that these rocks were produced by intense biotite-dehydration melting of pelitic rocks under ultra-high temperatures (UHT; 920-940 ${ }^{\circ} \mathrm{C}$ ) at lower-crustal depth (8.5-9.5 kbar; Galli et al. 2011). Polymineralic coronae and composite symplectites testify to an incomplete re-equilibration of the UHT peak assemblages at metamorphic conditions of 720-740 ${ }^{\circ} \mathrm{C}$ at 6.5-7.5 kbar (Galli et al. 2011) not dissimilar from the $750{ }^{\circ} \mathrm{C}, 5 \mathrm{kbar}$ determined by (Droop and Bucher-Nurminen 1984). These pressures and temperatures for coronae and symplectites fit well with the migmatisation conditions of the Gruf complex as well as with the mid-Tertiary regional metamorphism in the southern and south-eastern parts of the Lepontine dome $\left(700-750{ }^{\circ} \mathrm{C}\right.$ at 6-7.5 kbar, Fig. 8, e.g. Bucher-Nurminen and Droop 1983; Todd and Engi 1997; Stucki 2001; Nagel et al. 2002; Burri et al. 2005). Since metamorphic conditions of charnockites and granulites largely exceed the regional metamorphic conditions determined for the Lepontine metamorphism in the Central Alps, the charnockites and granulites preserve an earlier part of the metamorphic history. Nevertheless, the charnockites and granulites have suffered a complex history and zircon zones require an interpretation. Here, we follow Galli et al. (2012) who documented a polymetamorphic history based on U-Pb zircon dating of the charnockites. Zircons in the charnockites yielded 282-260 Ma with typical magmatic oscillatory features but have thin milky growth rims of 34-29 Ma (Galli et al. 2012). As discussed by Galli et al. (2012), the Permian age dates the formation of the charnockite melts while the Oligocene ages correspond to the Alpine metamorphism. The observations of Galli et al. (2012) are in full agreement with the observations but not the interpretation of Liati and Gebauer (2003): their zircons from the strongly residual granulite boulders yielded dominant oscillatory cores of $272 \pm 4 \mathrm{Ma}$ and thin milky rims of $32.7 \pm 0.5 \mathrm{Ma}$. They characterise the magmatic cores as to stem from a granitic s.l. precursor but then interpret the granulites as residual to such granites, $>90 \%$ melt extraction would then have occurred at $32.7 \pm 0.5 \mathrm{Ma}$.

As for other granulites in the Alps (e.g. Ivrea zone: Barboza and Bergantz 2000; Malenco unit: Müntener et al. 2000; Sesia zone: Lardeaux and Spalla 1991; Rebay and Spalla 2001; Sondalo complex: Braga et al. 2001; Braga et al. 2003), the UHT conditions in the Gruf complex were achieved during Permo-Triassic rifting (see data and discussion in Galli et al. 2012). Intense partial melting of pelitic rocks at deep crustal levels during a rifting-related thermal climax produced orthopyroxene-bearing charnockitic melts and strongly refractory, orthopyroxenesapphirine-bearing granulitic residuals. Further support of this view is provided by the association of the charnockites and granulites with websterites and gabbronorites, the latter of cumulative origin. This is typical for the post-Variscan high temperature event that characterises much of the European crust (Fig. 16a: cf. Lorenz and Nicholls 1976, 1984; Vielzeuf and Pin 1991; Rey 1993; Schuster and Stüwe 2008).

Diffusion modelling of the Gruf granulite garnets has shown that the charnockites and granulites ascended and cooled to $<550-600{ }^{\circ} \mathrm{C}$ within $20 \mathrm{Ma}$ of their formation (Galli et al. 2011). Consequently, at $240 \mathrm{Ma}$ ago, these lower crustal relicts were located at mid-crustal or shallower levels. At 34-29 Ma, the charnockites and granulites have then been partially overprinted during the Oligocene Alpine metamorphism. The incomplete re-equilibration of the granulitic peak-assemblage during the Lepontine event was partially a result of the severe loss of melt and the nearly complete dehydration during the UHT event (Galli et al. 2011).

Increased migmatisation over typically $<50 \mathrm{~m}$ and corundum-cordierite-bearing micaschists in the contact zone between the Gruf complex and the Bergell intrusion (Figs. 4, 7d, 9), together with back-veining of leucosomes from metasediments into the Bergell pluton (1 in Fig. 9) define a contact aureole. The increase in partial melting in this aureole could stem from an increase in temperature due to heat release from the pluton or to an influx of magmatic fluids released from the crystallising magma. Nevertheless, the prograde metamorphic corundum indicates a slight local increase in temperature with respect to the regional metamorphism already allowing for migmatisation (Fig. 8). The formation of a $<50 \mathrm{~m}$ thick contact aureole during Bergell emplacement at 33-30 Ma (Von Blanckenburg 1992, Oberli et al. 2004) would be in agreement with the countryrock being at upper amphibolite facies conditions of ca. 700-750 ${ }^{\circ} \mathrm{C}$ (Fig. 8). The small but petrologically well documented increase of temperature towards the Bergell contact constitutes a further argument against the previously suggested Oligocene age of the granulite facies 
a Permian situation: $290-280 \mathrm{Ma}$

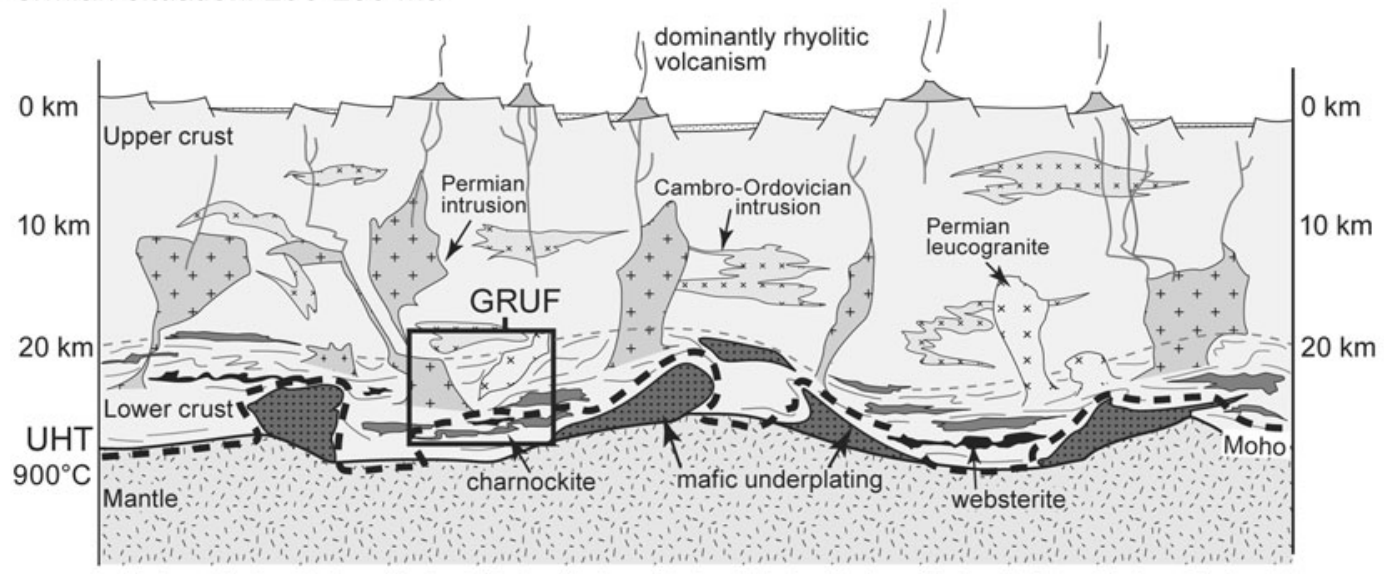

b Oligocene situation: $35-30 \mathrm{Ma}$
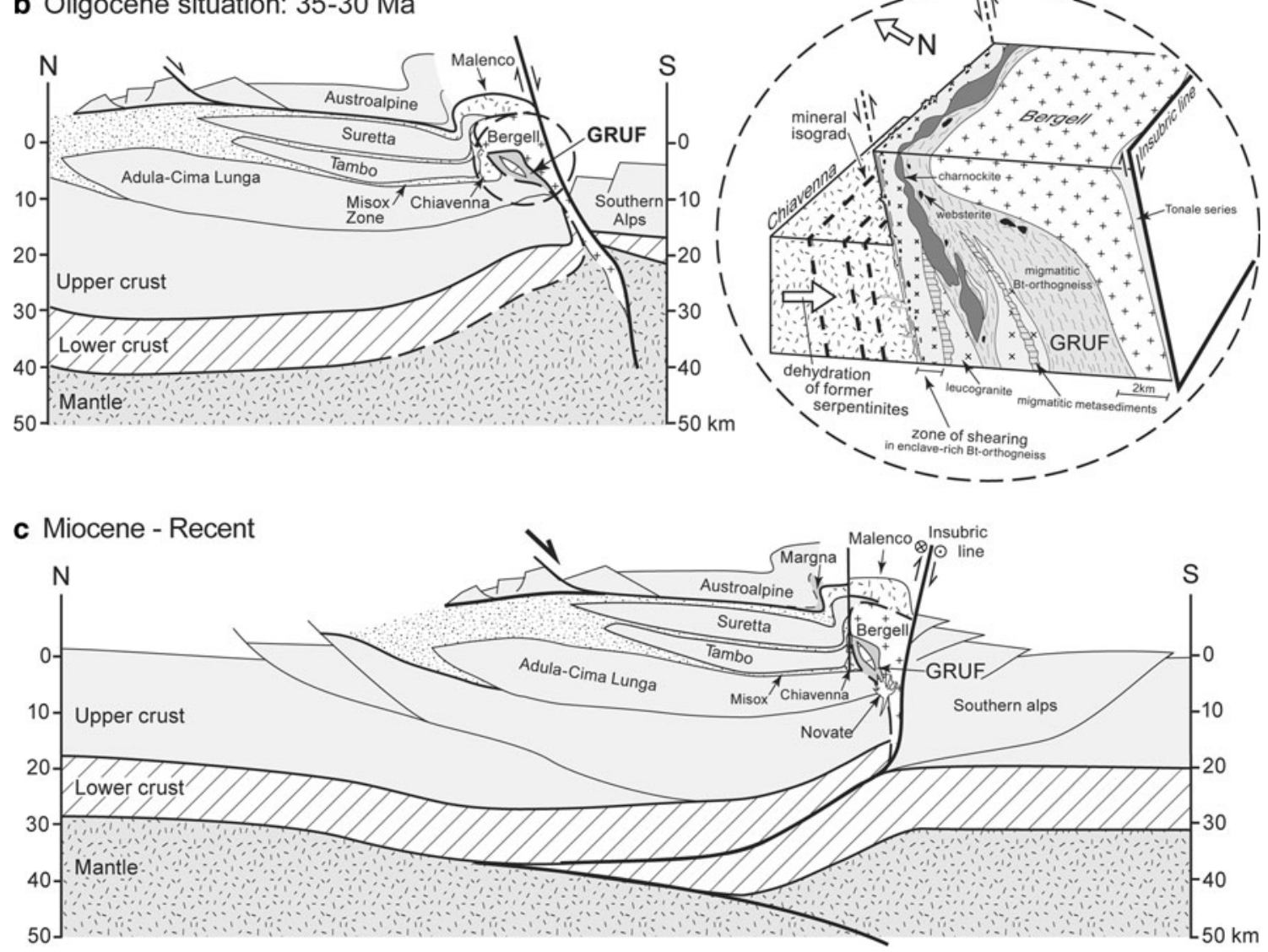

Fig. 16 Tectonic interpretation of the Gruf complex. a Situation during Permian rifting, charnockite intrusion and mafic underplating in the lower crust, granitic plutonism in the mid- to upper crust and surface volcanism; b oligocene Bergell intrusion, probably after slab breakoff, favouring exhumation of the migmatitic, lower crustal Gruf complex; c recent situation in the frame of the Central Alps following the interpretation of Burg et al. (2002). For details see text

crystallisation from granitic melts. These cores formed in Permian times in most of the samples from the Gruf complex (Galli et al. 2012, Liati and Gebauer 2003) and have thin homogeneous Oligocene-age rims formed at 34-29 Ma (Liati and Gebauer 2003; Galli et al. 2012). 
7.2 Juxtaposition of the Chiavenna unit and Gruf complex

The investigation of the northern contact between the Gruf complex and the Chiavenna unit does not confirm the Gruf line previously postulated by Schmutz (1976) or the presence of any particular fault zone. The Gruf line was inferred to be a fault zone along which relative uplift of the Gruf complex with respect to the Chiavenna unit has taken place (Bucher-Nurminen and Droop 1983; Berger et al. 1996). Detailed mapping of the northern contact of the Gruf complex showed only locally developed, centimetresthick and no more than a few meters long mylonite zones. This suggests that the deformation accompanying the ascent of the Gruf complex with respect to the Chiavenna unit and Tambo nappe was not localised within a narrow contact zone. Instead, we propose that the enclave-rich biotite-orthogneiss, or at least its northernmost part, acted as a low viscosity, magmatic sheet that accommodated exhumation of the Gruf complex (Fig. 16b). This would probably require remelting to near the rheologically critical melt fraction (Vigneresse et al. 1996). An indication of important re-melting is provided by extensive zircon rims that amount to 20-30\% of the zircon volume, which then crystallized with oscillatory patterns typical for granites and which yield ages of 32-31 Ma (Galli et al. 2012). During this movement, sheared off fragments of the Chiavenna unit have been incorporated into the biotiteorthogneiss, which thus became enclave-rich. This interpretation is consistent with the top-to-the NE (south-side up, dextral) shearing within this orthogneiss.

\subsection{A shared exhumation and emplacement history for the Gruf complex and the Bergell pluton?}

According to our work and that of previous authors (i.e. Rosenberg et al. 1995; Davidson et al. 1996; Berger et al. 1996; Schmid et al. 1996a) the intrusion of the Bergell pluton is contemporaneous with migmatisation and deformation of the Gruf complex. This clearly suggests that the two units share the same history since the Early Oligocene. The calc-alkaline magmas of the Bergell pluton and a few other smaller plutons to the north of the Insubric line were derived from a primitive mantle melt (Von Blanckenburg et al. 1992) and have been channelled from the base of the continental crust into the Periadriatic Fault system (Berger et al. 1996; Rosenberg 2004). We propose, in agreement with (Berger et al. 1996, their Fig. 16), that the dynamics of the ascending Bergell pluton triggered and helped exhumation of the migmatitic Gruf complex. The Gruf complex, perhaps together with the migmatite-rich Bellinzona-Dascio zone, acted as partially molten "lubricant" at the base and the northern side of the intrusion (Fig. 16b). In fact, migmatitic bodies related to the emplacement of calc-alkaline plutons are common in collisional orogenic belts (e.g. Soula 1982; Faure et al. 1999; Lin et al. 2007; Charles et al. 2009; Corsini and Rolland 2009). The ascending Bergell intrusion may have entrained crustal blocks containing charnockites, granulites and websterite to gabbronorite (Fig. 16b, c).This is a well-documented process (e.g. Best and Christiansen 2001) also reproduced in numerical models of magma emplacement (e.g. Gerya and Burg 2007).

Diffusion modelling of granulite garnets by Galli et al. (2011) has shown that the charnockites and granulites were at $<550-600{ }^{\circ} \mathrm{C}$ at $240 \mathrm{Ma}$. It remains unclear, at which point of the tectonometamorphic history the charnockites and granulites of the lower crust came into contact with the biotite-orthogneisses and supra-crustal metasediments that constitute the main mass of the Gruf complex and which do not document any granulite facies metamorphism. Three scenarios can be envisaged: (i) the charnockites formed in the lower crust but directly intruded the biotite-orthogneiss at shallower levels, transporting residual granulite enclaves with them. This possibility appears unlikely as the 920-940 ${ }^{\circ} \mathrm{C}$ hot charnockites should have produced contact metamorphism of the orthogneisses. (ii) The charnockites and granulites formed and remained originally in the lower crust and came into contact with the biotite-orthogneisses and metasediments of the middle crust around $240 \mathrm{Ma}$ ago when the charnockites and granulites were partly exhumed by extension and lithospheric thinning. However, homogeneous thinning would normally not alter the crustal "stratigraphy", thus, this scenario is unlikely to bring the charnockites into direct contact with the biotite-gneisses and metasediments. (iii) The charnockites and granulites formed in the lower crust during post-Variscan extension, were partly exhumed until $240 \mathrm{Ma}$ ago and were emplaced into the biotite-orthogneisses and metasediments during an early stage of exhumation of the Gruf complex and the Bergell intrusion. Alternative (iii) is our preferred scenario: (i) is at odds with the field observations, while (ii) would not truly lead to an incorporation of the granulite facies rocks into the gneisses. A Tertiary association of the granulites + charnockites in amphibolite facies gneisses would also allow for introducing the probably Mesozoic ophiolite remnants into the Gruf complex (see next section).

At variance with the term "line" used in previous studies, the differential movement of the Gruf complex did not occur along a discrete and narrow Gruf line but within an up to $2 \mathrm{~km}$ wide zone of shearing within the, at the time of activity of this shear zone, partially molten enclave-rich biotite-orthogneiss (Fig. 2). The juxtaposition of the hot Gruf complex against the upper greenschist to lowermost amphibolite facies rocks of the Chiavenna ophiolite caused dehydration of the serpentinites in the southern part of the same unit. The latter now exhibits an amphibolite facies 
olivine + opx + chlorite + spinel assemblage. We propose that these fluids locally increased the degree of melting in the adjacent biotite-orthogneiss leading to weakening and strain localisation. The partially molten enclave-rich biotite-orthogneiss thus acted in a crystalmush-like manner, accommodating the movement related to the exhumation of the Gruf complex. During this stage, shearing of mostly amphibolitic but also pelitic, ultramafic and calcareous fragments of the Chiavenna ophiolite occurred; these fragments now form the enclaves within this biotite-orthogneiss.

We follow previous authors (Bucher-Nurminen and Droop 1983; Schmid et al. 1996b; Talerico 2000) in that the exhumation of the Bergell intrusion, together with the hot Gruf complex, is thought to explain the vertical isograds and the metamorphic gradient from $\sim 450$ to $\sim 700{ }^{\circ} \mathrm{C}$ observed within $3 \mathrm{~km}$ across the Tambo nappe and the Chiavenna unit towards the Gruf complex (Fig. 16b: see Schmutz 1976; Talerico 2000). Indeed, Ar/ Ar ages on statically recrystallised amphibole grains of Chiavenna amphibolites show that this thermal gradient of $\sim 80{ }^{\circ} \mathrm{C} / \mathrm{km}$ formed between 33 and $30 \mathrm{Ma}$ (Talerico 2000), coeval with the emplacement of the Bergell pluton (Von Blanckenburg 1992) and with the Lepontine metamorphic peak in the Gruf complex (Galli et al. 2012).

\subsection{Metaperidotites and associated metabasic rocks:} remnants of a Mesozoic ocean?

Lenses of metaperidotites and associated amphibolites within the Gruf gneisses show many similarities to Mesozoic ophiolites from the southern part of the Central Alps. The occurrence of metamorphosed rodingite and ferrogabbro dykes within ultramafic lenses, and the geochemical affinity metabasalts to MORB displayed by the Gruf amphibolites near Bivacco Vaninetti (Diethelm 1989), testify for an oceanic origin of these rocks.

Ophiolitic relics from the Adula-Cima Lunga nappe complex (Evans et al. 1979; Pfiffner and Trommsdorf 1998), the Chiavenna unit (Schmutz 1976; Talerico 2000) and the Bellinzona-Dascio zone (Crespi 1965; Stucki et al. 2003) comprise metaperidotites with metamorphic rodingite dykes, amphibolites and calcsilicates. In the AdulaCima Lunga nappe complex and in the Bellinzona-Dascio zone, these are preserved as lenses embedded within migmatitic orthogneisses and metasediments (Schmidt 1989; Pfiffner and Trommsdorf 1998; Stucki et al. 2003). Given the petrological and geochemical similarities and the same mode of occurrence, we follow Diethelm (1989) in suggesting that the Gruf ultramafic-mafic rock associations are remnants of the same Mesozoic ocean. In the Bellinzona-Dascio zone, zircons from two plagiogranite dykes yielded SHRIMP ages of ca. 145 Ma (Stucki et al. 2003).
Based on this age they are interpreted as having formed during the late stage of magmatic activity in the PiemontLigurian realm. Zircons separated from the Chiavenna amphibolites, however, yielded younger formation ages of ca. $93 \mathrm{Ma}$ (Liati et al. 2003), leading the authors to assign the Chiavenna ophiolites to the Valais ocean. The absence of ages for the ophiolitic fragments of the Gruf complex does not allow an attribution to either the Piemont-Ligurian domain or the Valais ocean.

From a metamorphic point of view, the Gruf metaperidotites display the same peak mineral assemblage (chloriteolivine-enstatite-spinel) as the ultramafic boudins within the Bellinzona-Dascio zone (Stucki et al. 2003), suggesting that both were metamorphosed at temperatures slightly in excess of $700{ }^{\circ} \mathrm{C}$ (Fig. 8). These peridotites contrast with the ultramafic-mafic associations of the Adula-Cima Lunga nappe, which underwent eclogite facies metamorphism reaching 3-6 GPa (Heinrich 1982, 1986; Nimis and Trommsdorff 2001; Dale and Holland 2003; Brouwer et al. 2005). Evidence for a similar high pressure metamorphism was not found in the mafic and ultramafic rocks contained at the eastern margin of the Gruf complex. Together this suggests that the Gruf ophiolites have neither been exposed to granulite facies conditions nor been deeply subducted.

7.5 The Gruf complex in the framework of Alpine tectonics

The distinct style and orientation of deformation structures, in combination with the petrological differences, support the view that the evolution of the Gruf complex is different from that of other Central Alpine units before it was emplaced together with the Bergell intrusion. The Gruf complex itself is a lithological and structural coherent unit north of the northern limb of the Bergell intrusion (Fig. 1). The orientation of the ENE-WSW trending, heterogeneously developed main foliation on the east side of the northern Valle della Mera differs from those of the Adula on the west side and the features of strain localization within ductile shear zones are different from the sets (phases) of structures recognized in both the Adula nappe and Bellinzona-Dascio zone (e.g. Wenk 1973; Berger et al. 1996; Davidson et al. 1996; Schmid et al. 1996b; Meyre et al. 1998, Stucki 2001). The lack of regularly developed and systematic parasitic folds whose asymmetry would change from one limb to the other and the lack of a clearly defined hinge zone with $\mathrm{M}$ folds in the Gruf complex question the reality of the previously proposed large antiform within the Gruf complex (Moticska 1970; Wenk 1973; Wenk and Cornelius 1977; Davidson et al. 1996; Schmid et al. 1996a). Correlating the Gruf complex with the Adula nappe is thus disputable, both on structural and 
Fig. 17 Delimitation of migmatites (after Burri et al. 2005) and location of the sillimanite-K-feldspar isograds in the Central Alps. This isograd corresponds to the fluid-absent muscovite $(+$ plagioclase + quartz) melting (reaction 1 in the text) and is drawn following Burri et al. (2005) for the area around Bellinzona and according to this study for the Gruf complex. Swiss coordinates in kilometres

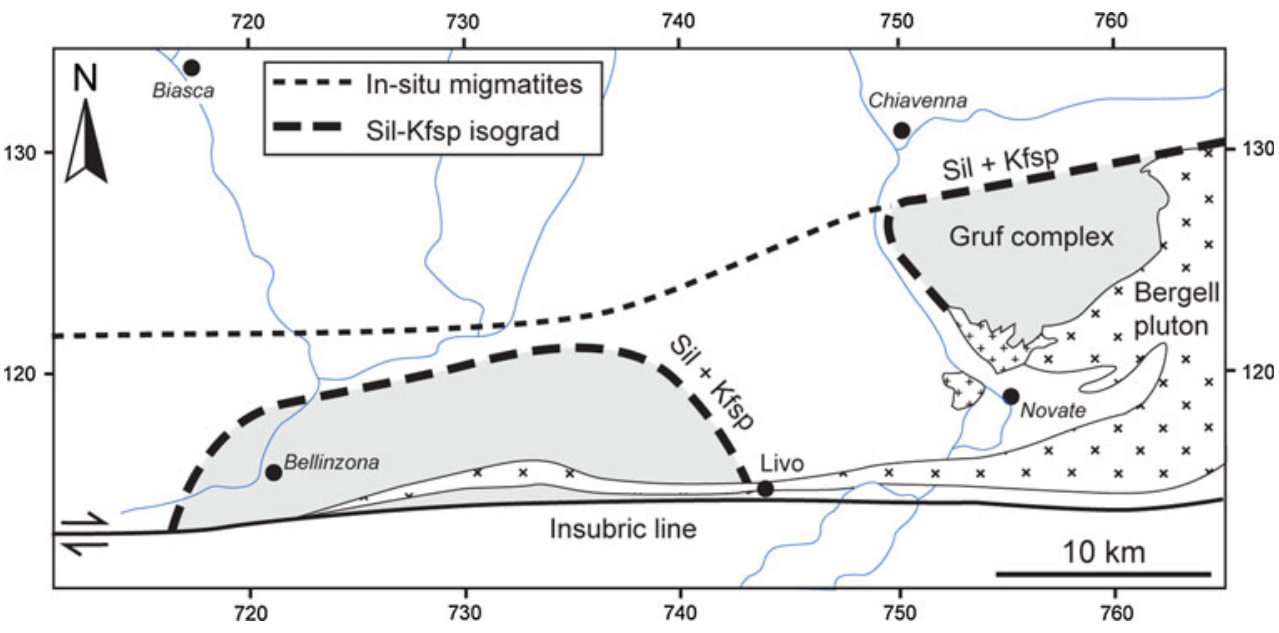

8 Conclusions

1. Detailed lithological and structural mapping of the Gruf complex permits the identification of sheets of charnockites and related granulites in their geological context, excluding any genetic link to the calc-alkaline Bergell pluton (e.g. as blocks of metapelites fallen into a tonalitic or more basic magma);

2. The metamorphic peak conditions (and deformation structures) in charnockites and granulites are $\sim 150-200{ }^{\circ} \mathrm{C}$ higher compared to those in other lithologies of the Gruf complex. This, together with radiometric age data published elsewhere, suggests that the charnockites and granulites document a polymetamorphic history starting with UHT metamorphism of Permian age within European lower crust, partly exhumed later and then re-equilibrated under upper amphibolite-facies conditions during the ascent of the Bergell intrusion;

3. The Gruf complex does not form a monogenetic unit but contains at least three components: the ultra-high temperature granulite + charnockite + websterite unit, the upper amphibolite facies, in part migmatitic gneisses, and the ophiolite remnants metamorphosed at upper amphibolite facies conditions during the Alpine stage;

4. The Gruf complex is interpreted as a migmatitic body associated with the Bergell pluton and distinct from other Penninic units, in particular from the Adula nappe;

5. Heat from the Bergell pluton produced a thin metamorphic contact aureole in the migmatitic rocks of the Gruf complex, responsible for the formation of corundum-cordierite micaschist, back-veining and for the increase of migmatisation in the immediate vicinity of the Bergell pluton.

Acknowledgments The ETH supported the authors of this study. We express our sincere thanks to Romain Bousquet and Stefan 
Schmid for their comments and helpful reviews, and to Geoff Milnes for his helpful suggestions and the editorial handling of this manuscript. This study benefited also from the unpublished ETH diploma theses of Hafner (1993), Hansmann (1981), Reusser (1981), Ruzicka (1997) and Schefer (2005).

\section{References}

Artus, F. (1959). Über metamorphe Breccien basischer Gesteine im Granit des Bergeller Massivs. Hamburger Beiträge zur Angewandten Mineralogie, Kristallphysik und Petrogenese, 2, 1-39.

Barboza, S. A., \& Bergantz, G. W. (2000). Metamorphism and anatexis in the mafic complex contact aureole, Ivrea zone, northern Italy. Journal of Petrology, 41, 1307-1327.

Baudin, T., \& Marquer, D. (1993). Metamorphism and deformation in the Tambo nappe (Swiss Central Alps): evolution of the phengite substitution during Alpine deformation. Schweizerische Mineralogische und Petrographische Mitteilungen, 73, 285-299.

Berger, A., Burri, T., Alt-Epping, P., \& Engi, M. (2008). Tectonically controlled fluid flow and water-assisted melting in the middle crust: an example from the Central Alps. Lithos, 102, 598-615.

Berger, A., Mercolli, I., \& Engi, M. (2005). The central Lepontine Alps: explanatory notes accompanying the tectonic-geological map sheet Sopra Ceneri (1:100'000). Schweizerische Mineralogische und Petrographische Mitteilungen, 85, 109-146.

Berger, A., Rosenberg, C., \& Schaltegger, U. (2009). Stability and isotopic dating of monazite and allanite in partially molten rocks: examples from the Central Alps. Swiss Journal of Geosciences, $102,15-29$.

Berger, A., Rosenberg, C., \& Schmid, S. M. (1996). Ascent, emplacement and exhumation of the Bergell pluton within the southern steep belt of the Central Alps. Schweizerische Mineralogische und Petrographische Mitteilungen, 76, 357-382.

Berger, A., Schmid, S.M., Engi, M. Bousquet, R. \& Wiederkehr, M. (2011). Mechanisms of mass and heat transport during Barrovian metamorphism: a discussion based on field evidence from the Central Alps (Switzerland/northern Italy). Tectonics, 30, TC1007, 1-17. doi:10.1029/2009TC002622.

Bernotat, W. H., \& Bambauer, H. U. (1982). The microcline/sanidine transformation isograd in metamorphic regions. I. The region of Lepontine metamorphism, central Swiss Alps. Schweizerische Mineralogische und Petrographische Mitteilungen, 62, 231-244.

Best, M. G., \& Christiansen, E. H. (2001). Igneous Petrology (p. 458). Malden: Blackwell Science Inc.

Bousquet, R., Goffé, B., Vidal, O., Oberhänsli, R., \& Patriat, M. (2002). The tectono-metamorphic history of the Valaisan domain from the western to the Central Alps: new constraints on the evolution of the Alps. Geological Society of America Bulletin, 114, 207-225.

Braga, R., Callegari, A., Messiga, B., Ottolini, L., Renna, M. R., \& Tribuzio, R. (2003). Origin of prismatine from the Sondalo granulites (Central Alps, northern Italy). European Journal of Mineralogy, 15, 393-400.

Braga, R., Giacomini, F., Messiga, B., \& Tribuzio, R. (2001). The Sondalo gabbroic complex (Central Alps, orthern Italy): evidence for emplacement of mantle-derived melts into amphibolite-facies metapelites. Physics and Chemistry of the Earth, Part A: Solid Earth and Geodesy, 26, 333-342.

Brouwer, F. M., Burri, T., Engi, M., \& Berger, A. (2005). Eclogite relics in the Central Alps: PT-evolution, Lu-Hf ages and implications for formation of tectonic mélange zones. Schweizerische Mineralogische und Petrographische Mitteilungen, 85, 147-174.
Bucher-Nurminen, K., \& Droop, G. (1983). The metamorphic evolution of garnet-cordierite-sillimanite-gneisses of the Grufcomplex, eastern Pennine Alps. Contributions to Mineralogy and Petrology, 84, 215-227.

Burg, J. P., Sokoutis, D., \& Bonini, M. (2002). Model-inspired interpretation of seismic structures in the Central Alps: crustal wedging and buckling at mature stage of collision. Geology, 30(7), 643-646.

Burri, T., Berger, A., \& Engi, M. (2005). Tertiary migmatites in the Central Alps: regional distribution, field relations, conditions of formation, and tectonic implications. Schweizerische Mineralogische und Petrographische Mitteilungen, 85, 215-232.

Charles, N., Faure, M., \& Chen, Y. (2009). The Montagne Noire migmatitic dome emplacement (French Massiv Central): new insights from petrofabric and AMS studies. Journal of Structural Geology, 31, 1423-1440.

Chatterjee, N. D., \& Johannes, W. (1974). Thermal stability and standard thermodynamic properties of synthetic $2 \mathrm{M}_{1}$-Muscovite, $\mathrm{KAl}_{2}\left[\mathrm{AlSi}_{3} \mathrm{O}_{10}(\mathrm{OH})_{2}\right]$. Contributions to Mineralogy and Petrology, 48, 89-114.

Cherniak, D. J., Watson, E. B., Grove, M., \& Harrison, T. M. (2004). $\mathrm{Pb}$ diffusion in monazite: a combined RBS/SIMS study. Geochimica et Cosmochimica Acta, 68, 829-840.

Ciancaleoni, L., \& Marquer, D. (2006). Syn-extension leucogranite deformation during convergence in the eastern Central Alps: example of the Novate intrusion. Terra Nova, 18, 170-180.

Cornelius, H. P. (1916). Ein alpines Vorkommen von Sapphirin. Cbl. für Mineralogie, 11, 265-269.

Corsini, M., \& Rolland, Y. (2009). Late evolution of the southern European Variscan belt: exhumation of the lower crust in a context of oblique convergence. Comptes Rendus Geosciences, $341,214-223$.

Crespi, R. (1965). Migmatiti e rocce verdi di Bagni di Masino del Masino. Istituto Lombardo Accademico Scienze e Lettere, 99.

Dale, J., \& Holland, T. J. B. (2003). Geothermobarometry, P-T paths and metamorphic field gradients of high-pressure rocks from the Adula nappe, Central Alps. Journal of Metamorphic Geology, $21,813-829$.

Davidson, C., Rosenberg, C., \& Schmid, S. M. (1996). Synmagmatic folding of the base of the Bergell pluton, Central Alps. Tectonophysics, 265, 213-238.

Diethelm, K.H. (1989). Petrographische und geochemische Untersuchungen an basischen Gesteinen der Bergeller Intrusion. PhD Thesis, ETH Zurich, Nr. 8855.

Droop, G., \& Bucher-Nurminen, K. (1984). Reaction textures and metamorphic evolution of sapphirine-bearing granulites from the Gruf complex, Italian Central Alps. Journal of Petrology, 25, 766-803.

Dunham, A. C. (1964). A petrographic and geochemical study of back-veining and hybridization ay a gabbro-felsite contact in Coire Dubh, Rhum, Inverness-shire. Mineralogical Magazine, 33, 887-902.

Engi, M., Berger, A., \& Roselle, G. (2001). The role of the tectonic accretion channel in collisional orogeny. Geology, 29, 1143-1146.

Evans, B. W., \& Guggenheim, S. (1988). Talc, pyrophyllite and related minerals. Reviews in Mineralogy, 19, 225-294.

Evans, B. W., Trommsdorff, V., \& Richter, W. (1979). Petrology of an eclogite-meta-rodingite suite at Cima di Gagnone, Ticino. American Mineralogist, 64, 15-31.

Faure, M., Lin, W., Shu, L., \& Sun, Y. (1999). Tectonics of the Dabieshan (eastern China) and possible exhumation mechanism of ultra high-pressure rocks. Terra Nova, 11, 251-258.

Frey, M. \& FerreiroMählmann, R. (1999). Alpine metamorphism of the Central Alps. SchweizerischeMineralogische und Petrographische Mitteilungen, 79, 135-154. 
Froitzheim, N., Schmid, S. M., \& Conti, P. (1994). Repeated change from crustal shortening to orogen-parallel extension in the Austroalpine units of Graubünden. Eclogae Geologicae Helvetiae, 87, 559-612.

Galli, A., Le Bayon, B., Schmidt, M. W., Burg, J. P., \& Reusser, E. (2011). Granulites and charnockites of the Gruf complex: evidence for Permian ultra-high temperature metamorphism in the Central Alps. Lithos, 124, 17-45.

Galli, A., Le Bayon, B., Schmidt, M.W., Burg, J.P., Reusser, E., Sergeev, S.A., \& Larionov, A. (2012). U-Pb zircon dating of the Gruf Complex: disclosing the late Variscan granulitic lower crust of Europe stranded in the Central Alps. Contributions to Mineralogy and Petrology, 163(2), 353-378.

Gebauer, D. (1996). A P-T-t path for an (ultra?-) high-pressure ultramafic/mafic rock-association and its felsic country-rocks based on SHRIMP-dating of magmatic and metamorphic zircon domains. Example: Alpe Arami (Central Swiss Alps). In: A. Basu \& S.R. Hart (Eds.), Earth Processes: Reading the Isotopic Code. Geophysics Monograph Serie, 95, 269-276. American Geophysics Union, Washington, DC.

Gerya, T. V., \& Burg, J.-P. (2007). Intrusion of ultramafic magmatic bodies into the continental crust: numerical simulation. Physics of the Earth and Planetary Interiors, 160, 124-142.

Ghizzoni, S., \& Mazzoleni, G. (2005). Itinerari mineralogici in Val Codera. Geologia Insubrica-Rivista di Scienze della Terra (Milano-Morbio Inferiore).

Gregory, C., McFarlane, C., Hermann, J., \& Rubatto, D. (2009). Tracing the evolution of calcalkaline magmas: in-situ Sm-Nd isotope studies of accessory minerals in the Bergell Igneous Complex, Italy. Chemical Geology, 260, 73-86.

Gulson, B. L. (1973). Age relations in the Bergell region of the southeast Swiss Alps: with some geochemical comparisons. Eclogae Geologicae Helvetiae, 66, 293-313.

Handy, M. R., Herwegh, M., \& Regli, C. (1993). Tektonische Entwicklung der westlichen Zone von Samedan (Oberhalbstein, Graubünden, Schweiz). Eclogae Geologicae Helvetiae, 86, $785-817$.

Hänny, R., Grauert, B., \& Soptrajanova, G. (1975). Paleozoic migmatites affected by high-grade Tertiary metamorphism in the Central Alps (Valle Bodengo, Italy). A geochronological study. Contributions to Mineralogy and Petrology, 51, 173-196.

Heinrich, C. A. (1982). Kyanite-eclogite to amphibolite facies evolution of hydrous mafic and pelitic rocks, Adula nappe, Central Alps. Contributions to Mineralogy and Petrology, 81, 30-38.

Heinrich, C. A. (1986). Eclogite facies regional metamorphism of hydrous mafic rocks in the Central Aline Adula nappe. Journal of Petrology, 27, 123-154.

Huber, R. (1999). Tectonometamorphic evolution of the eastern Pennine Alps during tertiary continental collision: structural and petrological relationships between Suretta, Tambo, Chiavenna and Gruf units (Switzerland/Italy). PhD Thesis, University of Neuchâtel.

Hutton, D. H. W. (1988). Granite emplacement mechanisms and tectonic controls: inferences from deformation studies. Transactions of the Royal Society Edinburgh, 79, 245-255.

Jenkins, D. M., \& Chernosky, J. V. (1986). Phase-equilibria and crystallochemical properties of Mg-chlorite. American Mineralogist, 71, 924-936.

Köppel, V., Günthert, A., \& Grünenfelder, M. (1981). Patterns of $\mathrm{U}-\mathrm{Pb}$ zircon and monazite ages in polymetamorphic units of the Swiss Alps. Schweizerische Mineralogische und Petrographische Mitteilungen, 61, 97-119.

Lardeaux, J. M., \& Spalla, M. I. (1991). From granulites to eclogites in the Sesia zone (Italian Western Alps): a record of the opening and closure of the Piedmont ocean. Journal of Metamorphic Geology, 9, 35-59.

Liati, A., \& Gebauer, D. (2003). Geochronological constraints for the time of metamorphism in the Gruf Complex (Central Alps) and implications for the Adula-Cima Lunga nappe system. Schweizerische Mineralogische Petrographische Mitteilungen, 83, 159-172.

Liati, A., Gebauer, D., \& Fanning, C. M. (2000). U-Pb SHRIMPdating of zircon from the Novate granite (Bergell, Central Alps): evidence for Oligocene-Miocene magmatism, Jurassic/Cretaceous continental rifting and opening of the Valais trough. Schweizerische Mineralogische Petrographische Mitteilungen, 80, 305-316.

Liati, A., Gebauer, D., \& Fanning, C. M. (2003). The youngest basic oceanic magmatism in the Alps (Late Cretaceous; Chiavenna unit, Central Alps): geochronological constraints and geodynamic significance. Contributions to Mineralogy and Petrology, 146, 144-158.

Lin, W., Ebami, M., Faure, M., Schärer, U., \& Arnaud, N. (2007). Survival of eclogite xenolith in a Cretaceous granite intruding the Central Dabieshan migmatite gneiss dome (eastern China) and its tectonic implications. International Journal of Earth Sciences, 96, 707-724.

Lorenz, V., \& Nicholls, I. A. (1976). The Permocarboniferous basin and range Province of Europe. An application of plate tectonics. In H. Falke (Ed.), The Continental Permian in Central, West, and South Europe (pp. 313-342). Dordrecht: D. Reidel Publishing Company.

Lorenz, V., \& Nicholls, I. A. (1984). Plate and intraplate processes of Hercynian Europe during the Late Paleozoic. Tectonophysics, 107, 25-56.

Meyre, C., De Capitani, C., Zack, T., \& Frey, M. (1999). Petrology of high-pressure metapelites from the Adula nappe (Central Alps, Switzerland). Journal of Petrology, 40, 199-213.

Meyre, C., Marquer, D., Schmid, S., \& Ciancaleoni, L. (1998). Synorogenic extension along the Forcola fault: correlation of Alpine deformations in the Tambo and Adula nappes (eastern Penninic Alps). Eclogae Geologicae Helvetiae, 91, 409-420.

Milnes, A. G., \& Pfiffner, A. O. (1980). Tectonic evolution of the Central Alps in the cross section St. Gallen-Como. Eclogae Geologicae Helvetiae, 73, 619-633.

Moticska, P. (1970). Petrographie und Strukturanalyse des westlichen Bergeller Massivs und seines Rahmens. Schweizerische Mineralogische und Petrographische Mitteilungen, 50, 355-443.

Müntener, O., Hermann, J., \& Trommsdorff, V. (2000). Cooling history and exhumation of lower crustal granulite and upper Mantle (Malenco, eastern Central Alps). Journal of Petrology, 41, 175-200.

Nagel, T., De Capitani, C., \& Frey, M. (2002). Isograds and P-T evolution in the eastern Lepontine Alps (Graubünden, Switzerland). Journal of Metamorphic Geology, 20, 309-324.

Niggli, E., \& Niggli, C. (1965). Karten der Verbreitung einiger Mineralien der alpidischen Metamorphose in den Schweizer Alpen (Stilpnomelan, Alkali-Amphibol, Chloritoid, Staurolith, Disthen, Sillimanit). Eclogae Geologicae Helvetiae, 58, 335-368.

Nimis, P., \& Trommsdorff, V. (2001). Revised Thermobarometry of Alpe Arami and other Garnet Peridotites from the Central Alps. Journal of Petrology, 42, 103-115.

Nussbaum, C., Marquer, D., \& Biino, G. G. (1998). Two subduction events in a polycyclic basement: alpine and pre-Alpine highpressure metamorphism in the Suretta nappe, Swiss Eastern Alps. Journal of Metamorphic Geology, 16, 591-605.

Oberli, F., Meier, M., Berger, A., Rosenberg, C., \& Gieré, R. (2004). $\mathrm{U}-\mathrm{Th}-\mathrm{Pb}$ and ${ }^{230} \mathrm{Th} /{ }^{238} \mathrm{U}$ disequilibrium isotope systematics: precise accessory mineral chronology and melt evolution tracing 
in the Alpine Bergell intrusion. Geochimica et Cosmochimica Acta, 68, 2543-2560.

Oterdoom, W. (1980). Scapolite in metamorphic calcsilicate rocks: crystallographic and phase relations. PhD Thesis, ETH, Zurich, Nr. 6657.

Paterson, S. R., Vernon, R. H., \& Tobisch, O. T. (1989). A review of criteria for the identification of magmatic and tectonic foliations in granitoids. Journal of Structural Geology, 11, 349-363.

Pfiffner, M., \& Trommsdorf, V. (1998). The high-pressure ultramaficmafic-carbonate suite of Cima Lunga-Adula, Central Alps: excursions to Cima di Gagnoneand Alpe Arami. Schweizerische Mineralogische und Petrographische Mitteilungen, 78, 337-354.

Powell, R., \& Holland, T.J.B. (2008). On thermobarometry. Journal of Metamorphic Geology, 26, 155-179.

Rebay, G., \& Spalla, M. I. (2001). Emplacement at granulite facies conditions of the Sesia-Lanzo metagabbros: an early record of Permian rifting? Lithos, 58, 85-104.

Reusser, E. (1987a). Phasenbeziehungen im Tonalit der Bergeller Intrusion. PhD Thesis, ETH Zurich, Nr. 8329.

Reusser, E. (1987b). Phasenbeziehungen im Tonalit der Bergeller Intrusion. Bericht über die 62. Hauptversammlung in Luzern, Schweizerische Moneralogische und Petrographische Mitteilungen, 67, 377-378.

Rey, P. (1993). Seismic and tectonometamorphic characters of the Lower continental crust in Phanerozoic areas: a consequence of post-thickening extension. Tectonics, 12, 580-590.

Ring, U. (1992). The Alpine geodynamic evolution of Penninic nappes in the eastern Central Alps: geothermobarometric and kinematic data. Journal of Metamorphic Geology, 10, 33-53.

Rosenberg, C. (2004). Shear zones and magma ascent: a model based on a review of the tertiary magmatism in the Alps. Tectonics, 23, TC3002. doi:10.1029/2003TC001526.

Rosenberg, C., Berger, A., \& Schmid, S. M. (1995). Observations from the floor of a granitoid pluton: inferences on the driving force of final emplacement. Geology, 23, 443-446.

Rubatto, D., Hermann, J., Berger, A., \& Engi, M. (2009). Protracted fluid-present melting during Barrovian metamorphism in the Central Alps. Contributions to Mineralogy and Petrology, 158(6), 703-722.

Schmid, S.M., Aebli, H.R., Heller, F., Zingg, A. (1989). The role of the Periadriatic line in the tectonic evolution of the Alps. In: D. Dietrich \& M.D. Coward (Eds.), Alpine Tectonics, vol 45 (pp. 153-171). London: Geological Society of London Special Publications.

Schmid, S. M., Berger, A., Davidson, C., Gieré, R., Hermann, J., Nievergelt, P., et al. (1996a). The Bergell pluton (Southern Switzerland, Northern Italy): overview accompanying a geological-tectonic map of the intrusion and surrounding country rocks. Schweizerische Mineralogische und Petrographische Mitteilungen, 76, 329-355.

Schmid, S. M., Pfiffner, O. A., Froitzheim, N., Schönborn, G., \& Kissling, E. (1996b). Geophysical-geological transect and tectonic evolution of the Swiss-Italian Alps. Tectonics, 15, 1036-1064.

Schmid, S. M., Rück, P., \& Schreurs, G. (1990). The significance of the Schams nappe for the reconstruction of the paleotectonic and orogenic evolution of the Penninic zone along the NFP 20 East Traverse. In A. Pfiffner \& P. Heitzmann (Eds.), Deep structure of the Alps-results from NFP/PNR 20 (pp. 263-287). Basel: Birkhäuser AG.

Schmid, S. M., Zingg, A., \& Handy, M. (1987). The kinematics of movements along the Insubric line and the emplacement of the Ivrea Zone. Tectonophysics, 135, 47-66.

Schmidt, M. W. (1989). Petrography and structural evolution of ophiolitic remnants in the Bellinzona Zone, Southern Steep Belt,
Central Alps (CH, I). Schweizerische Mineralogische Petrogrographische Mitteilungen, 69, 393-405.

Schmitz, S., Möller, A., Wilke, M., Malzer, W., Kannigiesser, B., Bousquet, R., et al. (2009). Chemical U-Th-Pb dating of monazite by 3D-Micro X-ray fluorescence analysis with synchrotron radiation. European Journal of Mineralogy, 21, 927-945.

Schmutz, H. (1976). Der Mafitit-Ultramafitit-Komplex zwischen Chiavenna und Val Bondasca (Provinz Sondrio, Italien; Kanton Graubünden, Schweiz). Beiträge zur Geologischen Karte der Schweiz (N.F.), 149, 73p.

Schuster, R., \& Stüwe, K. (2008). Permian metamorphic event in the Alps. Geology, 36, 603-606.

Soula, J.-C. (1982). Characteristics and mode of emplacement of gneiss domes and plutonic domes in central-eastern Pyrenees. Journal of Structural Geology, 4, 313-342.

Staub, R. (1946). Geologische Karte der Berninagruppe und ihrer Umgebung im Oberengadin, Bergell, Val Malenco, Puschlav und Livigno, 1:50'000. Geologische Spezialkarte 118, Schweizerische Geologische Kommission.

Steck, A., \& Hunziker, J. (1994). The tertiary structural and thermal evolution of the Central Alps-compressional and extensional structures in an orogenic belt. Tectonophysics, 238, 229-254.

Steinmann, M., \& Stille, P. (1999). Geochemical evidence for the nature of the crust beneath the eastern north Penninic basin of the Mesozoic Tethys Ocean. Geologische Rundschau, 87, 633-643.

Stucki, A. (2001). High grade Mesozoic ophiolites of the southern steep belt, Central Alps. PhD Thesis, ETH Zurich, No. 14206.

Stucki, A., Rubatto, D., \& Trommsdorff, V. (2003). Mesozoic ophiolite relics in the Southern Steep Belt of the Central Alps. Schweizerische Mineralogische und Petrographische Mitteilungen, 83, 285-299.

Talerico, C. (2000). Petrological and chemical investigation of a metamorphosed oceanic crust-mantle section (Chiavenna, Bergell Alps). PhD Thesis, ETH, Zurich, Nr. 13934.

Todd, C. S., \& Engi, M. (1997). Metamorphic field gradients in the Central Alps. Journal of Metamorphic Geology, 15, 513-530.

Trommsdorff, V. (1966). Progressive Metamorphose kieseliger Karbonatgesteine in den Zentralalpen zwischen Bernina und Simplon. Schweizerische Mineralogische und Petrographische Mitteilungen, 46, 431-460.

Trommsdorff, V. (1990). Metamorphism and tectonics in the Central Alps: the Alpine lithospheric melange of Cima Lunga and Adula. Memorie della Società Geologica Italiana, 45, 39-49.

Trümpy, R. (1960). Paleotectonic evolution of the central and western Alps. Bulletin of the Geological Society of America, 71, 1-104.

Vernon, R. H. (2000). Review of microstructural evidence of magmatic and solid-state flow. Electronic Geosciences, 5, 1-23. doi:10.1007/s10069-10000-10002-10063.

Vielzeuf, D., \& Holloway, J. R. (1988). Experimental determination of the fluid-absent melting relations in the pelitic system. Consequences for crustal differentiation. Contributions to Mineralogy and Petrology, 98, 257-276.

Vielzeuf, D., \& Montel, J. M. (1994). Partial melting of metagreywackes. Part I. Fluid-absent experiments and phase relationships. Contributions to Mineralogy and Petrology, 117, 375-393.

Vielzeuf, D., \& Pin, C. (1991). Late-Hercynian granulites of igneous origin-example of the Treilles Norite, Corbieres (Aude, France). Bulletin de la Société Géologique de France, 162, 1057-1066.

Vigneresse, J. L., Barbery, P., \& Cuney, M. (1996). Rheological transitions during partial melting and crystallization with application to felsic magma segregation and transfer. Journal of Petrology, 37, 1579-1600. 
Von Blanckenburg, F. (1992). Combined high-precision chronometry and geochemical tracing using accessory minerals: applied to the Central-Alpine Bergell intrusion. Chemische Geologie, 100, $19-40$.

Von Blanckenburg, F., Früh-Green, G., Diethelm, K., \& Stille, P. (1992). Nd-, Sr-, O-isotopic and chemical evidence for a twostage contamination history of mantle magma in the CentralAlpine Bergell intrusion. Contributions to Mineralogy and Petrology, 110, 33-45.

Wenk, E. (1955). Eine Strukturkarte der Tessiner Alpen. Schweizerische Mineralogische und Petrographische Mitteilungen, 35, 311-319.

Wenk, H.-R. (1970). Zur Regionalmetamorphose und Ultrametamorphose der Zentralalpen. Fortschritte der Mineralogie, 47, 34-51.

Wenk, H.-R. (1973). The structure of the Bergeller Alps. Eclogae Geologicae Helvetiae, 66, 255-291.

Wenk, H.-R. (1982). A geological history of the Bergell granite and related rocks. In: F.K. Drescher-Kaden \& S.S. Augustithis (Eds.), Transformists petrology (pp. 113-148). Athens: Theophrastus Publications.

Wenk, H.-R. (1986). Introduction to the geology of the Bergell Alps with guide for excursions. Jber. Natf. Gesellschaft Graubünden, 103, 29-90.

Wenk, H.-R. (1992). Note esplicative. Foglio 70 Sciora. Servizio idrologico e geologico nazionale.
Wenk, H., \& Cornelius, S. (1977). Geologischer Atlas der Schweiz, 1:25'000. Blatt Sciora: Publikationen der Schweizerischen Geologischen Kommission.

Wenk, H. R., Hsiao, J., Flowers, G., Weibel, M., Ayranci, B., \& Fejér, Z. (1977). A geochemical survey of granitic rocks in the Bergell Alps. Schweizerische Mineralogische und Petrographische Mitteilungen, 57, 233-265.

Wenk, H. R., Wenk, E., \& Wallace, J. H. (1974). Metamorphic mineral assemblages in pelitic rocks of the Bergell Alps. Schweizerische Mineralogische und Petrographische Mitteilungen, 54, 507-554.

Wiederkehr, M., Bousquet, R., Schmid, S.M., Berger, A. (2008). From subduction to collision: thermal overprint of HP/LT metasediments in the north-eastern Lepontine dome (Swiss Alps) and consequences regarding the tectono-metamorphic evolution of the Alpine orogenic wedge. In: N. Froitzheim, \& S.M. Schmid (Eds.), Orogenic processes in the Alpine collision zone. Swiss Journal of Geosciences, 101(Suppl 1), S127-S155.

Winther, K. T., \& Newton, R. C. (1991). Experimental melting of hydrous low-K tholeiite: evidence on the origin of Archean cratons. Bulletin of the Geological Society of Denmark, 39, 213-228.

Zulbati, F. (2008). Structural and metamorphic evolution of the phengite-bearing schists of the northern Adula Nappe (Central Alps, Switzerland). Geological Journal, 43, 33-57. 